\title{
The Araceae in Ceará, Brazil: humid forest plants in a semi-arid region
}

\author{
As Araceae no Ceará, Brasil: plantas de florestas úmidas encravadas no semi-árido
}

\author{
Ivanilza Moreira de Andrade ${ }^{1,5}$, Simon Joseph Mayo ${ }^{2}$, Maria Francilene Souza Silva ${ }^{1}$, \\ Danilo José Lima de Sousa ${ }^{3}$, Lígia Queiroz Matias ${ }^{3}$ \& Thales Alves Ribeiro ${ }^{4}$
}

\begin{abstract}
The study consists of a taxonomic treatment of the Araceae of Ceará, a state lying within Brazil's semi-arid region. The aroid flora shows greater similarity to those of central Brazil and Amazonia than to the Atlantic forest. Most species occur in humid forest fragments - the "florestas serranas". Geophytes are also found in caatinga and dry forest (Taccarum ulei) and lithophytes on rock outcrops in dry forest (Philodendron acutatum). Floating aquatics occur in ponds and lakes throughout the state (Pistia stratiotes, Lemna aequinoctialis, Lemna minuta, Spirodela intermedia, Wolffia columbiana, Wolffiella welwitschii), and freshwater helophytes (Montrichardia linifera) along river margins. 28 taxa (species and varieties) in 19 genera are described and most are illustrated: Anthurium (three spp.), Caladium (one sp.), Dieffenbachia (one sp.), Dracontium (one sp.), Lemna (two spp.), Monstera (two spp., one with two varieties), Montrichardia (one sp.), Philodendron (four spp.), Pistia (one sp.), Scaphispatha (one sp.), Spathicarpa (one sp.), Spathiphyllum (one sp.), Spirodela (one sp.), Syngonium (one sp.), Taccarum (one sp.), Wolffia (one sp.), Wolffiella (one sp.), Xanthosoma (two spp.), Zomicarpa (one sp.). New records for Ceará are Dieffenbachia aglaonematifolia, Dracontium nivosum, Monstera adansonii var. laniata, Philodendron sp. aff. ruthianum and the naturalized exotic Typhonium roxburghii. An identification key and data on geographic distribution and conservation status are provided.
\end{abstract}

Key words: Monocotyledons, semiarid region, floristics, florestas serranas, Geocat.

\section{Resumo}

O trabalho apresenta estudo taxonômico das Araceae no Ceará, estado que se enquadra na região semi-árida brasileira. A similaridade de taxa é maior com Brasil Central e Amazônia do que com a Mata Atlântica. A maioria das espécies ocorre nas florestas úmidas serranas. Geófitas podem ser ainda encontradas em caatinga e floresta seca (Taccarum ulei) e litófitas em afloramentos rochosos (Philodendron acutatum). Aquáticas flutuantes (Pistia stratiotes, Lemna aequinoctialis, Lemna minuta, Spirodela intermedia, Wolffia columbiana, Wolffiella welwitschii) e helófitas (Montrichardia linifera) ocorrem em água doce em todo o Estado. São descritos 28 taxa (espécies e variedades) distribuídos em 19 gêneros, na sua maioria ilustrados: Anthurium (três spp.), Caladium (uma sp.), Dieffenbachia (uma sp.), Dracontium (uma sp.), Lemna (duas spp.), Monstera (duas spp., uma com duas variedades), Montrichardia (uma sp.), Philodendron (quatro spp.), Pistia (uma sp.), Scaphispatha (uma sp.), Spathicarpa (uma sp.), Spathiphyllum (uma sp.), Spirodela (uma sp.), Syngonium (uma sp.), Taccarum (uma sp.), Wolffia (uma sp.), Wolffiella (uma sp.), Xanthosoma (duas spp.), e Zomicarpa (uma sp.). Os taxa registrados pela primeira vez para o estado foram: Dieffenbachia aglaonematifolia, Dracontium nivosum, Monstera adansonii var. laniata, Philodendron sp. aff. ruthianum e uma espécie exótica naturalizada, Typhonium roxburghii. Chave de identificação e dados sobre distribuição geográfica e estado de conservação são fornecidos. Palavras-chave: Monocotiledôneas, regiões semi-áridas, florística, florestas serranas, Geocat.

\section{Introduction}

The family Araceae Juss. currently consists of 126 genera and 3305 species (Boyce \& Croat 2012). It is sub-cosmopolitan in distribution and most species and genera occur in the tropics (Mayo et al. 1997). The family is very diverse in life form, morphology and anatomy (Grayum 1990), ranging from massive arborescent or epiphytic

\footnotetext{
${ }^{1}$ Universidade Federal do Piauí, Campus Parnaíba, Av. São Sebastião 2819, Parnaíba, PI, 64202-020, Brasil

${ }^{2}$ Royal Botanic Gardens, Herbarium, Kew, Richmond, Surrey, TW9 3AE, U.K.

${ }^{3}$ Universidade Federal do Ceará, Centro de Ciências, Depto. Biologia, bl. 906, Campus do Pici, 60451-760, Fortaleza, CE, Brasil.

${ }^{4}$ Universidade Estadual Vale do Acaraú - UVA, Curso de Ciências Biológicas, Av. da Universidade, Campus Betânia, Sobral, CE, Brasil.

${ }^{5}$ Corresponding author: ivanilzaandrade@hotmail.com
} 
herbs to minute floating aquatics (Bogner 1987; Croat 1990; Mayo et al. 1997). The duckweeds, formerly known as Lemnaceae S.F. Gray, are now subfamily Lemnoideae, a near-basal clade within Araceae (Cabrera et al. 2008; Cusimano et al. 2011). Armstrong (2012) is an excellent illustrated reference for duckweeds. The Araceae form the basal clade in the order Alismatales (Stevens 2001 onwards; APGIII 2009).

Braga's (1960) checklist, based on information from Ceará, includes many cultivated taxa and remains a useful source although the nomenclature is often out of date. Coelho et al. $(2010,2012)$ is currently the most complete checklist for Brazil. Andrade et al. (2006) published a checklist for Brazil's semi-arid region. Papers dealing with one or several species, mostly reports of new discoveries or records, have been published by Gonçalves \& Temponi (2004) and Bogner (1980). Population genetics and biogeography of Anthurium Schott and Monstera Adans. in the upland humid forests of Ceará have been studied by Andrade et al. (2007, 2009), who also studied leaf morphometrics in the same taxa (Andrade \& Mayo 2010; Andrade et al. 2008, 2010). Some Ceará species are included in more general revisions: Philodendron Schott: Sakuragui et al. (2006); Scaphispatha Brongn. ex Schott: Gonçalves (2005); tribe Spathicarpeae: Gonçalves (2002); Spathiphyllum Schott: Bunting (1960); Syngonium Schott: Croat (1981) and Zomicarpa Schott: Gonçalves (2012).

The state of Ceará lies within the semi-arid region of Northeast Brazil and is almost entirely covered with caatinga vegetation, a deciduous thorn forest (Figueiredo 1997). During the rainy season, temporary lakes and ponds with aquatic species are found throughout the landscape. Montane forests ("brejo forests") occur naturally where higher rainfall is caused by suitable combinations of humid winds, altitude, scarps and position (usually facing to the east and northeast). These areas are classified as remnants of formerly more extensive areas of Brazilian Atlantic Forest (Figueiredo 1997: "Floresta subperenifolia tropical pluvionebular"). Higher rainfall and lower temperatures allow the development of large evergreen trees and epiphytic and hemi-epiphytic flora in uplands on granitic geology at Baturité, Maranguape, Meruoca, Uruburetama, Pacatuba, and along the leading edge and scarp of sedimentary outcrops in northern Ibiapaba and the Chapada do Araripe (Oliveira \& Araújo 2007).
The aim of this study is to provide the first published taxonomic treatment for the State of Ceará of the family Araceae, plants which in this mostly semi-arid region are confined largely to relictual humid montane forest fragments (Andrade \& Mayo 2010).

\section{Material and Methods}

Field studies and collections were made at intervals during the period 2002 to 2012; collections from the following herbaria were studied: EAC, HCDAL, HST, IPA, JPB, K, MOSS, PEUFR, RB, TEPB, UFP, UFRN, URM (symbols as given by Thiers 2010). Our field collections were studied and processed at the following institutions: Universidade Estadual do Vale do Acaraú (UVA), Universidade Federal do Ceará (UFC) and Universidade Federal do Piauí (UFPI); the main collections are deposited at EAC, HUVA, $\mathrm{K}$, CEPEC and IPA. Municipal boundaries for Ceará are given in Matias \& Sousa (2011). We have cited before the species descriptions relevant illustrations published by Pott \& Cervi (1999), Lorenzi \& Souza (2001), Souza \& Lorenzi (2005) and Gonçalves \& Lorenzi $(2007,2011)$.

Biogeographical analysis was carried out using species distributions published by Coelho et al. (2012). Species native to Ceará were classified into five geographical categories, following Pontes $\&$ Alves (2011), adding information on life form and occurrence in the five Major Regions of Brazil (Tab. 1). Similarity in occurrence of the Ceará species between the five regions was computed in PAST ver. 2.15 (Hammer et al. 2001) using Jaccard's similarity and Euclidean distance (Sneath \& Sokal 1973).

Preliminary conservation status assessments within the state of Ceará were made for all species using the GEOCAT online tool (http://www. geocat.kew.org/), which uses range size (EOO: extent of occurrence; AOO: area of occupancy) estimated from the geographical coordinates of plant records (Rivers et al. 2011). We obtained latitude and longitude coordinates from GPS data or we estimated them from maps and Google Earth; the resulting data matrix is thus only provisional. Species known from less than five localities are assessed as Data Deficient (DD).

Only a single specimen is cited from each municipality (município) although our study is based on a larger array of material. A full list of the herbarium specimens studied is available from the 
Table 1 - Biogeographical and life form classification of the Araceae of Ceará. Based on the methods used by Pontes \& Alves (2011), using the species ranges reported by Coelho et al. (2012). Xanthosoma sagittifolium is not included here due to its status as only doubtfully native to Ceará.

\section{GROUP 1 PANTROPICAL AND INTERAMERICAN}

\begin{tabular}{llll}
\hline Species & Biogeographical classification & Brazilian Major Region & Habitat and life form in Ceará \\
\hline Anthurium scandens & Interamerican & $\mathrm{N}, \mathrm{NE}, \mathrm{CO}, \mathrm{SE}, \mathrm{S}$ & Humid forest, epiphyte \\
Caladium bicolor & Interamerican & $\mathrm{N}, \mathrm{NE}, \mathrm{CO}, \mathrm{SE} . \mathrm{S}$ & Humid forest, geophyte \\
Lemna aequinoctialis & Pantropical and subtropical & $\mathrm{N}, \mathrm{NE}, \mathrm{CO}, \mathrm{SE} . \mathrm{S}$ & Lakes and ponds, floating aquatic \\
Lemna minuta & Interamerican & $\mathrm{N}, \mathrm{NE}, \mathrm{S}$ & Lakes and ponds, floating aquatic \\
Pistia stratiotes & Pantropical & $\mathrm{N}, \mathrm{NE}, \mathrm{CO}, \mathrm{SE}, \mathrm{S}$ & Lakes and ponds, floating aquatic \\
Spirodela intermedia & Interamerican & $\mathrm{N}, \mathrm{NE}, \mathrm{CO}, \mathrm{SE}, \mathrm{S}$ & Lakes and ponds, floating aquatic \\
Wolffia columbiana & Interamerican & $\mathrm{NE}, \mathrm{CO}, \mathrm{S}$ & Lakes and ponds, floating aquatic \\
Wolffiella welwitschii & Interamericanand Africa tropical & $\mathrm{NE}, \mathrm{CO}$ & Lakes and ponds, floating aquatic
\end{tabular}

\section{GROUP 2 SOUTH AMERICAN: AMAZONIA-ATLANTICA HUMID FOREST BIOMES}

\begin{tabular}{|c|c|c|c|}
\hline $\begin{array}{l}\text { Monstera adansonii var. } \\
\text { klotzschiana }\end{array}$ & S. America disjunct & $\mathrm{N}, \mathrm{NE}, \mathrm{CO}, \mathrm{SE}, \mathrm{S}$ & Humid forest, hemi-epiphyte \\
\hline Monstera adansonii var. laniata & S. America disjunct & $\mathrm{N}, \mathrm{NE}$ & Humid forest, hemi-epiphyte \\
\hline Monstera praetermissa & S. America disjunct & $\mathrm{N}, \mathrm{NE}, \mathrm{CO}, \mathrm{SE}, \mathrm{S}$ & Humid forest, hemi-epiphyte \\
\hline Montrichardia linifera & S. America continuous & $\mathrm{N}, \mathrm{NE}, \mathrm{SE}$ & River margins, helophyte \\
\hline Philodendron acutatum & S. America continuous & $\mathrm{N}, \mathrm{NE}, \mathrm{CO}, \mathrm{SE} ?$ & $\begin{array}{l}\text { Humid forest and exposed rock } \\
\text { outcrops, , hemi-epiphyte }\end{array}$ \\
\hline Philodendron sp. aff. ruthianum & S. America disjunct & $\mathrm{N}, \mathrm{NE}, \mathrm{SE}$ & Humid forest, hemi-epiphyte \\
\hline Philodendron ornatum & S. America disjunct & $\mathrm{N}, \mathrm{NE}, \mathrm{SE}$ & Humid forest, hemi-epiphyte \\
\hline Philodendron pedatum & S. America disjunct & $\mathrm{N}, \mathrm{NE}, \mathrm{CO}, \mathrm{SE}$ & Humid forest, hemi-epiphyte \\
\hline Syngonium vellozianum & S. America disjunct & $\mathrm{N}, \mathrm{NE}, \mathrm{CO}, \mathrm{SE}, \mathrm{S}$ & Humid forest, hemi-epiphyte \\
\hline \multicolumn{4}{|c|}{ GROUP 3 SOUTH AMERICAN: CENTRAL BRAZILIAN } \\
\hline Anthurium affine & Brasil & $\mathrm{NE}, \mathrm{CO}, \mathrm{SE}$ & $\begin{array}{l}\text { Seasonal forest, exposed rock } \\
\text { outcrops }\end{array}$ \\
\hline Anthurium sinuatum & S. American & $\mathrm{N}, \mathrm{NE}, \mathrm{CO}, \mathrm{SE}, \mathrm{S}$ & Humid forest, hemi-epiphyte \\
\hline Dieffenbachia aglaonematifolia & S. American & $\mathrm{NE}, \mathrm{CO}, \mathrm{S}$ & Humid forest, terrestrial herb \\
\hline Scaphispatha gracilis & S. American & $\mathrm{N}, \mathrm{NE}, \mathrm{CO}$ & Seasonal forest, geophyte \\
\hline Spathicarpa gardneri & Brazil & $\mathrm{N}, \mathrm{NE}, \mathrm{CO}, \mathrm{SE}$ & Humid forest, geophyte \\
\hline Spathiphyllum gardneri & S. American & $\mathrm{N}, \mathrm{NE}, \mathrm{CO}$ & Humid forest, terrestrial herb \\
\hline Xanthosoma pentaphyllum & Brazil & $\mathrm{NE}, \mathrm{CO}, \mathrm{SE}$ & Humid forest, geophyte \\
\hline \multicolumn{4}{|l|}{ GROUP 4 AMAZONIAN } \\
\hline Dracontium nivosum & Brazil & $\mathrm{N}, \mathrm{NE}$ & Humid forest, geophyte \\
\hline \multicolumn{4}{|c|}{ GROUP 5 BRAZIL: NORTH-EASTERN } \\
\hline Taccarum ulei & Brazil & $\mathrm{NE}$ & $\begin{array}{l}\text { Caatinga, dry forest, humid } \\
\text { forest, geophyte }\end{array}$ \\
\hline Zomicarpa pythonium & Brazil & $\mathrm{NE}$ & Dry forest, geophyte \\
\hline
\end{tabular}


first author (I.M. de Andrade). All specimens cited have been seen by the authors unless otherwise indicated.

A determination list of all specimens cited is provided in Annex 2, given in alphabetic order of collectors' names.

\section{Results and Discussion}

We recorded 28 native species and varieties in 19 genera for Ceará: Anthurium affine Schott, $A$. scandens (Aubl.) Engl., A sinuatum Benth. ex Schott, Caladium bicolor (Aiton) Vent., Dieffenbachia aglaonematifolia Engl., Dracontium nivosum (Lem.) G.H. Zhu, Lemna aequinoctialis Welw., L. minuta Kunth, Monstera adansonii Schott var. klotzschiana (Schott) Madison, M. adansonii var. laniata (Schott) Madison, M. praetermissa E.G.Gonç. \& Temponi, Montrichardia linifera (Arruda) Schott, Philodendron acutatum Schott, P. ornatum Schott, $P$. pedatum (Hook.) Kunth, P. sp. aff. ruthianum Nadruz, Pistia stratiotes L., Scaphispatha gracilis Brongn. ex Schott, Spathicarpa gardneri Schott, Spathiphyllum gardneri Schott, Spirodela intermedia W. Koch, Syngonium vellozianum Schott, Taccarum ulei Engl. \& K.Krause, Wolffia columbiana H.Karst., Wolffiella welwitschii (Hegelm.) Monod, Xanthosoma pentaphyllum (Schott) Engl., X. sagittifolium (L.) Schott, Zomicarpa pythonium (Mart.) Schott. Another five species from exotic genera (Alocasia (Schott) G.Don, Colocasia Schott, Epipremnum Schott, Typhonium Schott and Zantedeschia Spreng.) and a second species of Dieffenbachia Schott were recorded as naturalized in Ceará, i.e. growing and reproducing freely, although often near to dwellings or agricultural areas (see Annex 1). The many species of Araceae found only in cultivation are not recorded here (see e.g. Lorenzi \& Souza 2001).

Of the native species, 16 occur only in humid forests (Tab. 1), two in both humid and dry forests (Philodendron acutatum, Taccarum ulei), three in dry or seasonal forests (Anthurium affine, Scaphispatha gracilis, Zomicarpa pythonium), six are floating aquatics occurring throughout the state in seasonal or permanent lakes and ponds and one is a helophyte along river margins in areas of humid microclimate (Montrichardia linifera). The following species are recorded for Ceará for the first time: Dieffenbachia aglaonematifolia, Dracontium nivosum, Philodendron sp. aff. ruthianum, Typhonium roxburghii. The humid forest areas of the state are thus where the main diversity of the family is to be found and in particular, all the epiphytes and hemi-epiphytes (Tab. 1).

Although there are no species of Araceae endemic to Ceará state, there is a unique mixture of elements from Amazonia, Central Brazil and the Atlantic Forest. Andrade et al. (2007, 2008, 2009, 2010; Andrade \& Mayo 2010) studied four widespread humid forest taxa (Monstera adansonii var. klotzschiana, M. praetermissa, Anthurium pentaphyllum, A. sinuatum) and compared genetic and morphological relations between populations in Ceará, Amazonia and the Atlantic Forest. They demonstrated a closer relationship between the westernmost upland forest (Ibiapaba) and Amazonian populations in Anthurium sinuatum (Andrade et al. 2008; Andrade \& Mayo 2010), a pattern suggesting recent humid forest connections with Amazonia. The ranges so far recorded for Dracontium nivosum, Dieffenbachia aglaonematifolia, Scaphispatha gracilis and Syngonium vellozianum also suggest that Ibiapaba has a stronger biogeographical relationship to Amazonia and Central Brazil than to the more eastern upland forests of Ceará.

The species are divided into five biogeographical groups, following the geographical analyses of Gonçalves (2004) on central Brazilian Araceae and Pontes \& Alves (2011) on Araceae of Pernambuco.

Group 1 (Tab. 1) with eight species, consists of pantropical or interamerican taxa occurring in North, Central and South America, and/or the Caribbean. Six of these are floating aquatics (Lemna aequinoctialis, L. minuta, Pistia stratiotes, Spirodela intermedia, Wolffiella welwitschii and Wolffia columbiana) which typically have wide distributions (Santamaría 2002). Two are geophytes of humid forest habitat (Caladium bicolor, Xanthosoma sagittifolium) with ranges that have been influenced by human migration (Madison 1981). However, the epiphytic and rupicolous species Anthurium scandens seems to have a naturally very wide range, possibly due to bird dispersal (Carlo \& Aukema 2005).

Group 2 consists of nine widespread tropical South American taxa, seven of which are hemiepiphytes in the genera Monstera, Philodendron and Syngonium confined to humid forest biomes of Amazonia and the Atlantic Forest. Montrichardia linifera is a helophyte mostly restricted to freshwater (sometimes brackish water) habitats within humid forest biomes, but the hemi-epiphyte Philodendron acutatum also occurs in more exposed habitats such as rock outcrops in more 
seasonal environments (Sakuragui et al. 2006; Maia et al. 2010). Andrade et al. (2007) suggested that the presence in Ceará of Monstera adansonii var. klotzschiana may be due to Holocene forest expansion across the Brazilian Shield.

Group 3 consists of species typical of the Cerrado province of Central Brazil (Gonçalves 2004; Gonçalves \& Coelho 2009; Coelho et al. 2012; Tropicos.org 2012); some are known from few specimens and most are absent from the humid Atlantic Forest of eastern littoral Brazil. Anthurium affine is an exception, reaching the coastal area in northeastern Brazil where it occurs in open coastal restinga vegetation and on exposed rock outcrops rather than in humid forest. Anthurium sinuatum also occurs in Amazonia, but around its northern and western margins. Dieffenbachia aglaonematifolia extends south to Paraguay and northern Argentina and from western Paraná to Maranhão in Brazil. Scaphispatha gracilis extends across Brazil near the southern margin of Amazonia from Ceará to Bolivia. Spathicarpa gardneri is restricted to Brazil, extending further east and southeast, but not as far as the humid Atlantic coastal forest (Gonçalves 2002) and Xanthosoma pentaphyllum has a very similar distribution. Spathiphyllum gardneri occurs in Amazonia as well as in central Brazil.

Group 4, comprising strictly Amazonian species, includes only Dracontium nivosum, hitherto known from Pará and Amazonian Maranhão. Group 5 consists of two species known only from the northeastern Major Region of Brazil. Taccarum ulei occurs in caatinga and semi-deciduous seasonal forest (Gonçalves 2002) and Zomicarpa pythonium is found generally in seasonal vegetation types including coastal restinga forest in Bahia (Gonçalves 2012).

A numerical comparison of the Ceará taxa with those of the Major Regions of Brazil (Tab. 2) suggests that the predominant biogeographic connections are with Amazonia and the Central Brazilian cerrado biome, apart from the high expected similarity with the Northeast region within which Ceará lies. It is notable that all those species in Ceará which are shared with the Atlantic Forest, also occur in Amazonia (Tab. 1). Our comparison is based on the data presented by Coelho et al. (2012) which is not definitive since new records and new discoveries of Brazilian Araceae are constantly being made. Our comparison does not take into account the species which are absent from Ceará. The lack of endemic aroid taxa in Ceará suggests that at least some humid forest species may have become extinct during periods of increasing aridity. Likely sources for inward immigration into humid areas in Ceará during more mesophytic periods may have been Amazonia and Central Brazil, with the Atlantic Forest region perhaps having a lesser role.

The preliminary conservation status assessments given for each species refer to the situation within the state of Ceará based on existing herbarium specimen records. The Araceae of Ceará remain very under-collected and our results are only provisional; most species are known from less than the minimum reliable number of 15 specimens recommended by Rivers

Table 2 - Comparison of Araceae flora of Ceará with those of the Major Regions of Brazil. Based on the methods used by Gonçalves (2004). Computed in PAST ver. 2.15 (Hammer et al. 2001) using data from Coelho et al.(2012). Key to Major Regions: CE: Ceará.N (Norte): Acre, Amapá, Amazonas, Pará, Rondônia, Roraima, Tocantins. NE (Nordeste without CE): Alagoas, Bahia, Maranhão, Paraíba, Pernambuco, Piauí, Rio Grande do Norte, Sergipe. CO (CentroOeste): Goiás, Mato Grosso, Mato Grosso do Sul. SE (Sudeste): Espírito Santo, Minas Gerais, Rio de Janeiro, São Paulo. S (Sul): Paraná, Santa Catarina, Rio Grande do Sul.

\begin{tabular}{|c|c|c|c|c|c|c|}
\hline \multicolumn{7}{|c|}{ Jaccard's similarity coefficient } \\
\hline & $\mathrm{CE}$ & $\mathrm{N}$ & $\begin{array}{c}\text { NE } \\
\text { (without CE) }\end{array}$ & $\mathrm{CO}$ & SE & $\mathrm{S}$ \\
\hline $\mathrm{CE}$ & 1.00 & & & & & \\
\hline $\mathrm{N}$ & 0.74 & 1.00 & & & & \\
\hline $\begin{array}{l}\text { NE } \\
\text { (without CE) }\end{array}$ & 0.89 & 0.69 & 1.00 & & & \\
\hline $\mathrm{CO}$ & 0.70 & 0.56 & 0.59 & 1.00 & & \\
\hline SE & 0.63 & 0.68 & 0.58 & 0.64 & 1.00 & \\
\hline S & 0.44 & 0.45 & 0.33 & 0.55 & 0.45 & 1.00 \\
\hline \multicolumn{7}{|c|}{ Euclidean distance } \\
\hline & $\mathrm{CE}$ & $\mathrm{N}$ & $\begin{array}{c}\mathrm{NE} \\
\text { (without CE) }\end{array}$ & $\mathrm{CO}$ & SE & $\mathrm{S}$ \\
\hline $\mathrm{CE}$ & 0 & & & & & \\
\hline $\mathrm{N}$ & 2.65 & 0 & & & & \\
\hline $\begin{array}{l}\mathrm{NE} \\
\text { (without CE) }\end{array}$ & 1.73 & 2.83 & 0 & & & \\
\hline $\mathrm{CO}$ & 2.83 & 3.32 & 3.32 & 0 & & \\
\hline SE & 3.16 & 2.65 & 3.32 & 2.83 & 0 & \\
\hline S & 3.87 & 3.46 & 4.24 & 3.00 & 3.32 & 0 \\
\hline
\end{tabular}


et al. (2011). Despite these severe limitations, the results of the conservation analysis highlight the threat to the humid forest fragments and show that the basic geographical data of a floristic study can generate a useful, though incomplete picture of the conservation status of the species. No species is restricted to Ceará and so assessments based on their full range will differ.

Agriculture is well developed in most areas of humid upland forest visited during this study (Maranguape, Aratanha, Baturité, Uruburetama, Meruoca and Planalto do Ibiapaba). Tourism and outdoor leisure activities such as rock climbing, camping and mountain biking are also important in these areas and have had a negative impact on the forests through fires, pollution by garbage, soil erosion along trails and deforestation. Dracontium nivosum, for example, was found on steep forest slopes covered with an extensive layer of refuse which had accumulated from an urban area above.

The greatest aroid diversity was found only in restricted "islands" of more constant humidity, shade and temperature within the upland forested areas, in humid stream valleys, on slopes subject to constant humid winds and around waterfalls protected from dry air by rock outcrops. In contrast, the remaining areas covered with evergreen forest experience a dry season sufficiently strong to prevent the survival of aroid epiphytes and hemi-epiphytes and the only species observed in these areas were geophytes like Taccarum ulei, Caladium bicolor and Xanthosoma pentaphyllum. The overall extent of evergreen or semi-evergreen forest is thus a poor guide to the total area of high plant diversity habitat, which must be considerably smaller. The most humid foci are where the highest diversity is found not only in the Araceae but probably also in other groups like Orchidaceae, Pteridophytes and Bryophytes. These areas are often especially favoured by visitors for bathing and picnics by waterfalls, which provides a further challenge for conservation policy.

The Serra de Maranguape is one of the best preserved areas although it has suffered much human impact. The humid forest occurs primarily on the ridges and upper slopes. Closed canopy forest alternates with open areas of cultivation and secondary vegetation. In the neighbouring Serra de Aratanha there are many areas of secondary vegetation with cultivation and the forest trails are used by motor cycles and visitors seeking bathing areas. The Serra de Aratanha seems to have the largest area of relatively undisturbed forest of all the upland forests visited during this study.

Three areas were visited within the montane complex of Baturité (Arvoredo - Pacoti, Álvaro - Guaramiranga and Olho d'água - Pacoti de Taguará), all of which have owners with a policy of forest preservation. In these localities the vegetation consisted of recuperating secondary forest with relatively small, often thin-stemmed trees. Bamboos and epiphytes were more common in the Sítio Álvaro. The Uruburetama forest has been reduced to a small fragment of secondary slope forest with the rest used mainly for banana plantations.

In the Chapada Ibiapaba we visited the municipalities of Ibiapina, São Benedito, Viçosa do Ceará, Ubajara and Tianguá. In Ibiapina the trail that leads to the Pajé waterfall has humid forest along the stream with large trees, surrounded by steep slopes, with disturbed and cultivated areas. Mata Fresca in São Benedito consists of a remnant of slope forest with waterfalls, around which were found epiphytes, hemi-epiphytes, ferns and mosses; it is much visited by tourists and we found much garbage there. Lajes in Viçosa do Ceará has low shrubby vegetation and exposed flat rock outcrops with rupicolous Cactaceae, Orchidaceae, Bromeliaceae and Araceae, as well as a more humid area of secondary forest. Along the trail to Pedra do Carangueijo in Viçosa do Ceará the slope forest was very humid and led to a waterfall much used for washing clothes by local people. Ferns, selaginellas and aroids were abundant in this locality, which was also notable for the amount of garbage.

The National Park of Ubajara is the most important conservation area for the upland forests of Ceará and preserves some of the original humid primary forest of the region but also includes drier forest types along its borders. According to a report by IBAMA (1999), timber extraction and cultivation of coffee and other crops were carried out within the Park area prior to its creation and part of the current vegetation remains in a late state of recuperation. In Tianguá a protected private estate was visited which consists of an extensive and gradually recuperating secondary forest. 


\section{Identification Key to the Araceae of Ceará*}

1. Plant a free-floating aquatic.

2. Plant body differentiated into a very short stem and rosulate leaves densely covered with conspicuous hairs; inflorescence with a distinct spathe, a single female flower and a single whorl of male flowers

9.1 Pistia stratiotes

2'. Plant body a single undifferentiated thallus, not differentiated into stem and leaves.

3. Roots absent.

4. Frond elongated to ovate, with air spaces within

17.1 Wolffiella welwitschii

4'. Frond globose, lacking air spaces 16.1 Wolffia columbiana

3'. Roots present.

5. Roots numerous on each frond

13.1 Spirodela intermedia

5'. Roots 1 on each frond.

6. Frond with 3 veins

5.1 Lemna aequinoctialis

6'. Frond usually lacking veins 5.2 Lemna minuta

1'. Plant a terrestrial herb, helophyte (rooted aquatic), root-climbing hemi-epiphyte, epiphyte or lithophyte, never a free-floating aquatic.

7. Leaf simple, entire, lanceolate, ovate, elliptic, oblanceolate or obovate.

8. Fine venation reticulate.

9. Plant a geophyte, stem a subterranean tuber, leaves often variegated with irregular greygreen patches, spathe entirely adnate to spadix 11.1 Spathicarpa gardneri

9'. Plant a lithophyte or epiphyte, stem epigeal or at soil level, leaves not variegated, spathe not adnate to spadix.

10. Plant a robust lithophyte, leaves $35-90 \mathrm{~cm}$ long, lacking dark punctations and with conspicuously undulate margins 1.1 Anthurium affine

10 '. Plant usually an epiphyte, leaves $5-13 \mathrm{~cm}$ long, with dark punctations on both sides, more numerous on the abaxial side, margins not undulate

1.2 Anthurium scandens

8'. Fine venation parallel to primary lateral veins.

11. Stem conspicuous, erect to decumbent with distinct, green internodes, petiole lacking an apical geniculum, spathe convolute basally, flowers unisexual.

12. Leaves usually conspicuously variegated with whitish green or yellowish green, plant associated with houses and gardens

Dieffenbachia seguine

12 '. Leaves always plain green with no variegation, plant typically found in natural populations on the banks of streams and in damp or flooded areas of humid forest 3.1 Dieffenbachia aglaonematifolia

11'. Stem inconspicuous, plant appearing to be acaulescent, internodes not visible, petiole with apical geniculum, spathe expanded, patent to erect, flowers bisexual

12.1 Spathiphyllum gardneri

7'. Leaf cordate, sagittate, hastate, panduriform-sagittate, pinnatifid-hastate, perforate, trisect, pedatisect or dracontioid (blade highly divided).

13. Petiole geniculate at apex.

14. Leaf pedatisect, peduncle much longer than spadix, flowers with a perigon, plant tissues lacking trichosclereids 1.3 Anthurium sinuatum

14'. Leaf ovate to oblong-elliptic, peduncle not very different in length from the spadix, flowers lacking perigon, tissues of the leaf and petiole with trichosclereids.

15. Leaf blade usually variegated with irregular white and yellow patches, not perforate, but large mature leaves often pinnatipartite along one side

Epipremnum aureum

15'. Leaf blade without variegation, mature leaves perforated and/or pinnatipartite.

16. Petiole green with numerous paler dots, sheath persistent, green entire and herbaceous, mature leaves perforate, usually maintaining entire margins.

*Note: The unnumbered names refer to non-native, naturalized species which are included in the key for convenience; see Annex 1 for details. 
17. Stylar region of gynoecium with conical apex

17'. Stylar region of gynoecium with flat apex

6.1.1 Monstera adansonii var. klotzschiana

6.1.2 Monstera adansonii var. laniata

16'. Petiole lacking paler dots, sheath rapidly marcescent, turning black-brown and eventually deciduous, mature leaves with large perforations that break at the margin to become deeply pinnatipartite ......

6.2 Monstera praetermissa

13'. Petiole lacking apical geniculum, or if visible then leaf dracontioid.

18. Leaf dracontioid (solitary leaf with blade divided into three major divisions which are themselves further much-subdivided).

19. Petiole smooth, flowers unisexual, plant relatively common in Ceará, in humid forest, dry forest, and caatinga 15.1 Taccarum ulei

19'. Petiole scabrose or with small projections especially towards the base, flowers bisexual, plant rare, recorded only in northern part of Chapada de Ibiapaba in humid forest

4.1 Dracontium nivosum

18'. Leaf cordate, sagittate, hastate, panduriform-sagittate, pinnatifid-hastate, perforate, trisect or pedatisect.

20. Stem epigeal, erect or climbing, internodes visible and green at least when first young.

21. Leaf blade pedatisect, plant a climbing hemi-epiphyte, stem with milky sap when cut 14.1 Syngonium vellozianum

21'. Leaf blade cordate, sagittate, panduriform-sagittate or pinnatifid-hastate, stem usually lacking milky sap (except juvenile Syngonium).

22. Leaf blade sagittate.

23. Plant a robust helophyte, stem erect to $4 \mathrm{~m}$ in height, rhizomatose at the base, occurring along stream and river banks 7.1 Montrichardia linifera

23'. Plant a root-climber, or a terrestrial or creeping herb when immature, occurring in humid forests or as a lithophyte on rock outcrops in drier forms of vegetation.

24. Leaf blade with distinct infra-marginal collective veins, stem with milky sap 14.1 Syngonium vellozianum (juvenile)

24'. Leaf blade without infra-marginal collective veins, stem lacking milky sap 8.1 Philodendron acutatum

22'. Leaf blade cordate, panduriform-sagittate or pinnatifid-hastate.

25. Blade cordate, petiole densely verrucose towards the apex 8.2 Philodendron ornatum

25'. Blade panduriform-sagittate or pinnatifid-hastate, petiole more-or-less smooth 26. Blade panduriform-sagittate 26'. Blade pinnatifid-hastate 8.4 Philodendron sp. aff. ruthianum 8.3 Philodendron pedatum

20'. Stem usually entirely hypogeal (sometimes the apical part epigeal in robust individuals of Alocasia macrorrhizos), plant a geophyte.

27. Leaf blade peltate-cordate to peltate-sagittate.

28. Secondary and tertiary lateral veins arising from the primaries at a wide or right angle and then following a strongly arching course towards the blade margin, without forming a conspicuous, sinuose interprimary collective vein

Colocasia esculenta

28'. Secondary and tertiary lateral veins arising from the primaries at a wide angle and joining into a sinuose or zig-zag interprimary collective vein between each pair of primary lateral veins.

29. Plant commonly associated with houses and gardens but also found in cultivated areas or shady plantations and secondary forest, leaf blade usually (but not always) variegated with red and/or white spots, blotches or tingeing, female zone of the spadix separated from male zone by a conspicuous thicker zone of sterile male flowers 2.1 Caladium bicolor 
29'. Plant rare, leaf blade not variegated, female zone of spadix contiguous with male zone or with a very few intermediate sterile male flowers 10.1 Scaphispatha gracilis

27'. Leaf blade cordate, sagittate, hastate, trisect or pedatisect but never peltate.

30. Leaf blade pedatisect or trisect.

31. Plant with milky sap, spathe blade white and marcescent after flowering, plant common and of medium stature, spadix without sterile terminal appendix

18.1 Xanthosoma pentaphyllum

31'. Plant without milky sap, spathe blade brown to green, persistent, plant rare, small in stature, spadix with mostly naked sterile terminal appendix

19.1 Zomicarpa pythonium

30'. Leaf blade cordate, sagittate or hastate.

32. Blade cordate or hastate, plant small in stature.

33. Blade cordate to emarginate at base, spathe entirely adnate to spadix, spadix without sterile terminal appendix

11.1 Spathicarpa gardneri

33'. Blade hastate, spathe not adnate to spadix, spadix with elongated, dark purple naked sterile terminal appendix

Typhonium roxburghii

32'. Blade sagittate, plant of medium to large stature.

34. Primary lateral veins not forming an infra-marginal collective vein, fine venation parallel to primaries Zantedeschia aethiopica

34'. Primary lateral veins joining into an infra-marginal collective vein on each side, fine veins arising from the primaries at a wide or right angle.

35. Secondary and tertiary lateral veins between each pair of primaries joining to form a sinuose or zig-zag interprimary collective vein ....... 18.2 Xanthosoma sagittifolium

35'. Secondary and tertiary lateral veins between each pair of primaries following a strongly arching course towards the leaf blade margin, without forming a conspicuous sinuose interprimary collective vein Alocasia macrorrhizos

\section{Taxonomic treatment}

\section{Anthurium Schott}

1.1. Anthurium affine Schott, Oesterr. Bot. Wochenbl. 5: 82. 1855. Gonçalves \& Lorenzi (2007: 196, 367, 408), (2011: 246, 451, 504).

Fig. 1a,b

Plant a lithophyte. Stem short, epigeal, often wedged into rock crevices, up to $4.0 \mathrm{~cm}$ long, internodes very short, roots numerous, white or pale green, ca. $0.5 \mathrm{~cm}$ diam., densely covering stem in a thick tangled layer, cataphylls persistent, membranaceous. Petiole 5.5-25 cm long, 0.6-1.6 $\mathrm{cm}$ diam., adaxially broadly sulcate with acute margins and sometimes with a central ridge, abaxially usually 3 -sulcate with flattened sides, geniculum paler than petiole. Leaves rosulate, blade 35-90 × 9-34 cm, entire, oblong, elliptic, obovate or oblanceolate, rigidly coriaceous, not variegated, adaxial side dark green, abaxial side paler, lacking dark punctations, margins strongly undulate, apex acute to rounded, sometimes cuspidate, base cuneate to rounded or subcordate, midrib adaxially prominent and distinctly angled, abaxially 3 -angled towards base and rounded to 1-angled towards apex, primary lateral veins 8-13 on each side, prominent on both surfaces, often yellowish green, curved upwards towards margins, not joined into an infra-marginal collective vein except sometimes in apical region, fine venation reticulate. Inflorescence erect, shorter than leaf as a whole, peduncle $21-65 \mathrm{~cm}$ long, $0.2-1.7 \mathrm{~cm}$ diam., green or purplish at apex, cylindric or 1-angled; spathe $2.5-12.5 \times 1.2-4.8 \mathrm{~cm}$, usually shorter than spadix, not adnate to spadix, oblong to ovate, green or with purplish margins, semi-erect or recurved, acuminate at apex, rounded to subcordate at base, decurrent on peduncle for $0.5-4.0 \mathrm{~cm}$; spadix $5-18$ cm long, $0.8-2.3 \mathrm{~cm}$ diam., subcylindric to clavate, yellow at anthesis becoming green and then grey after flowering, sessile or with stipe up to $4 \mathrm{~cm}$ long; flowers bisexual with a perigone of 4 tepals. Berry $1.3-1.6 \times 0.3-0.6 \mathrm{~cm}$, obovoid, cylindric or ellipsoid, glossy scarlet becoming dark purple at apex; seed $0.5-0.8 \times 0.2-0.3 \mathrm{~cm}$, narrowly oblanceolate to elliptic, somewhat flattened, khaki to pale yellow.

Selected material: Viçosa do Ceará, 4.III.2002, I.M. Andrade et al. 623 (EAC). 

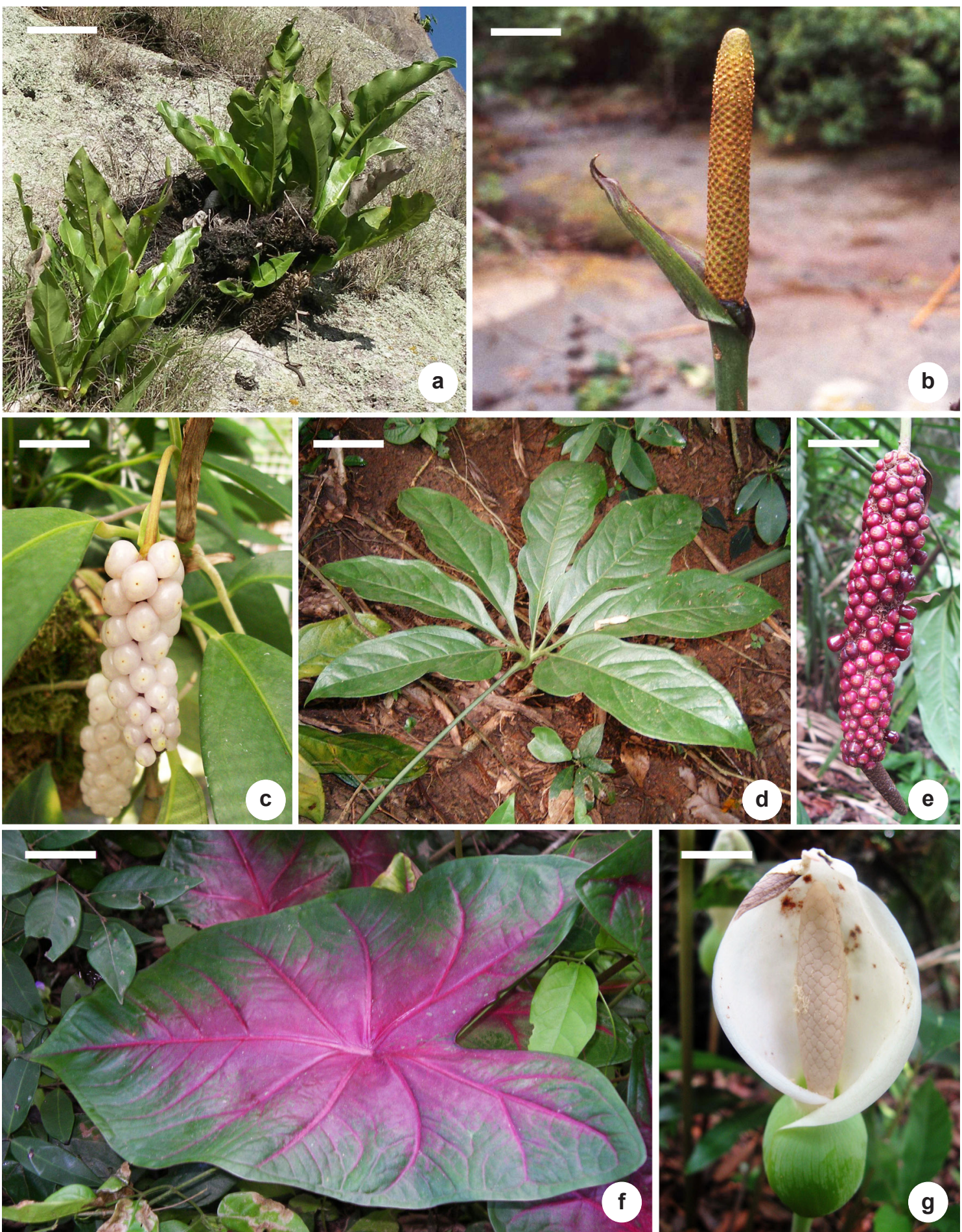

Figure 1 - a-b. Anthurium affine - a. habit, b. inflorescence; c. Anthurium scandens - infructescence. d-e. Anthurium sinuatum - d. leaf. e. infructescence. f-g. Caladium bicolor - f. leaf blade, g. inflorescence. Scale bars: $\mathrm{a}=20 \mathrm{~cm} ; \mathrm{b}=2$ $\mathrm{cm} ; \mathrm{c}=1.2 \mathrm{~cm} ; \mathrm{d}=6 \mathrm{~cm} ; \mathrm{e}=3.5 \mathrm{~cm} ; \mathrm{f}=2.5 \mathrm{~cm} ; \mathrm{g}=1.8 \mathrm{~cm}$. 
The species preliminary conservation status assessment within Ceará is Data Deficient. Only known from a single locality. It occurs in the Montane forest area of Ibiapaba. This species is very variable morphologically, but is usually distinctive by the short, thick spadix, tepals yellow at anthesis, and the strongly undulate leaf margins. Typically a lithophyte in areas of exposed or partially shaded rock outcrops.

1.2. Anthurium scandens (Aubl.) Engl. in Martius, Flora Brasiliensis 3(2): 78. 1878. Gonçalves \& Lorenzi (2007: 341), (2011: 86, 418). Fig. 1c

Epiphyte on tree trunks, often pendent, sometimes on rocks. Stem epigeal, branching, climbing, elongated with internodes $0.3-0.5 \mathrm{~cm}$ diam., the leafy portion covered with persistent, marcescent, net-fibrous, tubular, pale brown cataphylls. Petiole $1.0-6 \times 0.05-0.1 \mathrm{~cm}$, shorter than blade, geniculate at apex, canaliculate adaxially with angled margins, rounded abaxially. Leaf blade 5-13 $\times 2.5-4.8 \mathrm{~cm}$, entire, elliptic to ovate or obovate, coriaceous, margins not undulate, apex acute to obtuse, base cuneate to acute, not variegated, adaxial side dark green, abaxial side slightly paler, both sides covered with tiny dark punctations, denser abaxially, primary lateral veins numerous, hardly differentiated from secondaries, joining on each side into an inframarginal collective vein $0.3-0.5 \mathrm{~cm}$ from margin, fine venation reticulate. Inflorescence: peduncle $1.7-4 \times 0.75-0.1 \mathrm{~cm}, 0.9-1.9$ times longer than spadix; spathe $1-2 \times 0.2-0.4 \mathrm{~cm}$, shorter than spadix, not adnate to spadix, oblong to ovate, pale green, apex cuspidate; spadix 1.5-2.2 × $0.25-0.35 \mathrm{~cm}$, sessile, cylindric, pale green; flowers bisexual with a perigone of 4 tepals. Berry $0.6-0.7 \times 0.6-0.8 \mathrm{~cm}$, with 2-4 seeds, translucent white, obovoid to subglobose, slightly depressed at apex; seed $0.25-0.3 \times 0.13 \mathrm{~cm}$, slightly flattened, oblong, white, greenish at apex.

Selected material: Guaramiranga, 19.II.2002, I.M. Andrade et al. 534 (EAC). Itatira, 13.I.1981, A. Fernandes et al. (EAC 9635). Maranguape, 16.II.2002, I.M. Andrade et al. 511 (EAC). Pacatuba, 25.III.2000, E.B. Sousa et al. 427 (EAC). Pacoti, 11.XI.1998, F.S. Cavalcanti (EAC 28427). Uruburetama, 24.XI.1986, L.W. Lima-Verde (EAC 15319).

The species preliminary conservation status assessment within Ceará is Extent of Occurrence: Vulnerable (VU); Area of Occupancy: Vulnerable (VU). Based on 13 specimens from 13 localities. It occurs in the following Montane forest areas: Aratanha, Baturité, Maranguape, Uruburetama. Epiphyte in humid forest but also found on rocks.
The berry colour is white in Ceará, but in other parts of the neotropics it may be pale violet or purple (Croat 1983: 371).

1.3. Anthurium sinuatum Benth. ex Schott, Oesterr. Bot. Wochenbl. 7: 318. 1857. Souza \& Lorenzi (2005: 93). Gonçalves \& Lorenzi (2007: 318, 380), (2011: 392, 470). $\quad$ Fig. 1d,e

Root-climbing epiphyte. Stem epigeal with elongated internodes; cataphylls persistent, becoming brown and membranaceous. Petiole longer than leaf blade, green, cylindric and somewhat flattened adaxially towards the apex, apical geniculum prominent and continuous with the geniculate bases of the leaflets. Leaf blade compound, narrowly pedatisect or almost palmatisect, when mature with (3-)5-7(-9) leaflets, leaflets obovoid, oblanceolate, oblong or ellipsoid, adaxially darkish green and abaxially paler, \pm glossy on both surfaces, margins broadly and rather irregularly sinuate and undulate, central leaflet (10.4-)14.5-28.2(-33.3) × (2.3-)4.0-10.5(13.2) $\mathrm{cm}$ wide, primary lateral veins \pm impressed adaxially and prominent abaxially, joining to form an infra-marginal collective vein at least in the upper half of the leaflet, the rest terminating in the margin, the 3-5 central leaflets more symmetric with more distinct marginal lobing, the two external leaflets asymmetric with the outer side wider, and usually rounded to auriculate externally at the base. Inflorescence erect to decumbent, peduncle green, 13.0-45 cm long, cylindric, shorter than petiole; spathe shorter or equal to spadix, 6-20 × $1-2 \mathrm{~cm}$, green, adaxially paler and more glossy, erect, patent to somewhat reflexed, sometimes fornicate, usually persistent until fruit maturation; spadix $6-23 \mathrm{~cm}$ long, $0.4-0.8 \mathrm{~cm}$ diam., purple to violet during female anthesis, becoming brown and matte after male anthesis; flowers bisexual with a perigone of 4 tepals, anthers cream-coloured. Berries usually not developed in the apical part of the infructescence, berry entirely purplish red to vinaceous, glossy, at maturity extruded from tepals and pendent, apex rounded to slightly flattened, slightly obconic, mesocarp white; seed vinaceous, cordiform.

Selected material: Ibiapina, 1.III.2002, I.M. Andrade et al. 554 (EAC). São Benedito, 2.III.2002, I.M. Andrade et al. 577 (EAC). Guaramiranga, 19.II.2002, I.M. Andrade et al. 548 (EAC). Pacoti, 18.II.2002, I.M. Andrade et al. 529 (EAC). Maranguape, 10.VII.2003, I.M. Andrade 881 (EAC). Pacatuba, 17.II.2002, I.M. Andrade et al. 519 (EAC). Ubajara, 24.IX.1998, A. Fernandes et al. (EAC 27781). 
The species preliminary conservation status assessment within Ceará is Extent of Occurrence: Vulnerable (VU); Area of Occupancy: Near Threatened (NT). Based on 24 specimens from 17 localities. Collections at the Kew Herbarium (K) from elsewhere in Brazil suggest that this species may survive in less humid forest types and further field exploration in Ceará may widen its known occurrence beyond the confines of the humid forest fragments where it is presently recorded. It occurs in the following Montane forest areas: Aratanha, Baturité, Ibiapaba, Maranguape. In Ceará this species occurs in humid forests. Andrade (2006), Andrade et al. $(2009,2010)$ and Andrade \& Mayo (2010) published results from a combined morphometric and genetic study using AFLP markers carried out on populations of this species in Ceará.

\section{Caladium Ventenat}

2.1 Caladium bicolor (Aiton) Vent., Mag. Encycl. 4: 464. 1801, \& in Descr. pl. nouv. jard. Cels. 30, t.30. 1801 .

Fig. 1f,g

Terrestrial, medium-sized geophytic herb. Stem a subglobose, underground tuber. Leaves few, rosulate. Petiole 30-40 cm long, usually longer than blade, variegated with whitish to dark markings, the apical part darker, lacking apical geniculum. Leaf blade up to $35 \times 18 \mathrm{~cm}$, peltatecordate to peltate-sagittate, adaxially usually variegated, the most common patterns in natural populations being green with whitish midrib and basal ribs and a red spot at the petiole junction, or the central part of the blade, the midrib, basal ribs and primary lateral veins diffusely reddened and the marginal area remaining green, or the blade green with scattered white and red spots, abaxially paler, leaf apex shortly acuminate, posterior lobes rounded to obtuse, primary lateral veins of anterior lobe $2-3$ on each side, joining to form an inframarginal collective vein, a marginal vein also visible, primary lateral veins of each posterior lobe joined into a straight well-developed basal rib, secondary lateral veins arising from primaries at a wide angle and joining into a sinuose or zig-zag interprimary collective vein between each pair of primaries, finer venation reticulated. Inflorescence erect, peduncle shorter than petiole; spathe 8-14 $\mathrm{cm}$ long, with strong central constriction, lower part subglobose, forming a closed tube, green, ca. 3-4 cm long, upper part forming a longer, naviculiform white blade up to $12 \mathrm{~cm}$ long; spadix erect, a little shorter than the spathe, sterile zone separating male and female zones much thicker than rest of spadix and white; flowers unisexual, lacking perigone, male flowers (synandria) white, stigmas yellow. Fruits not seen.

Selected material: Guaramiranga, 19.II.2002, I.M. Andrade et al. 540 (HUEFS, EAC). Pacatuba, 17.II.2002, I.M. Andrade et al. 520 (K, HUEFS, EAC, UVA). Pacoti, 18.II.2002, I.M. Andrade et al. 530 (EAC). São Benedito, 6.I.1942, P. Bezerra (EAC 468). Tianguá, 6.III.2002, I.M. Andrade et al. 633 (HUEFS). Ubajara, 15.X.1998, I.M. Andrade et al. (EAC 28493). Viçosa do Ceará, 4.III.2002, I.M. Andrade et al. 625 (EAC).

The species preliminary conservation status assessment within Ceará is Extent of Occurrence: Vulnerable (VU); Area of Occupancy: Least Concern (LC). Based on 10 specimens from 8 localities. This species can be very common in suitable habitats and probably also occurs in many more localities that those so far recorded. It occurs in the following Montane forest areas: Aratanha, Baturité, Ibiapaba. Common in humid secondary forests and shaded plantations. The species common names are pinica-pau (Ceará), tajá, tinhorão (Braga 1960: 452).

\section{Dieffenbachia Schott}

3.1. Dieffenbachia aglaonematifolia Engl., Pflanzenr. IV, 23Dc (Heft 64): 61. 1915. Gonçalves \& Lorenzi (2007: 142, 164), (2011: 178, 207).

Fig. 2a,b

Helophytic herb, to $0.5-2 \mathrm{~m}$ in height. Stem erect to decumbent, with a strong odour when cut or crushed; internodes conspicuous, green, prophylls $6.6-9 \mathrm{~cm}$ long. Petiole $8.3-13.3 \mathrm{~cm}$ long, green, cylindric to somewhat sulcate adaxially, sheath more than $3 / 4$ the petiole length, green with whitish striae in basal part, lacking an apical geniculum. Leaf blade entire, oblong to ovate or oblong to elliptic, $13-35 \mathrm{~cm}$ long, $4.3-16.3 \mathrm{~cm}$ wide, coriaceous, adaxially dark green, abaxially paler with prominent midrib, apex cuspidate, base obtuse, margin entire, primary lateral veins ca. 9-11 on each side, terminating at the margin, fine venation parallel to primaries. Inflorescence: cut or broken tissue exuding whitish sap, peduncle 4.5$8.5 \mathrm{~cm}$ long; spathe 14-21.0 cm long, persistent, only slightly constricted, tube convolute, equal or longer than blade, green, blade becoming greenish cream; spadix 14.5-22 cm long, female zone 6-12 cm long, entirely adnate to spathe; sterile intermediate zone $1-2.8 \mathrm{~cm}$ long with lower half adnate to spathe, male zone $6-8.3 \mathrm{~cm}$, free from 

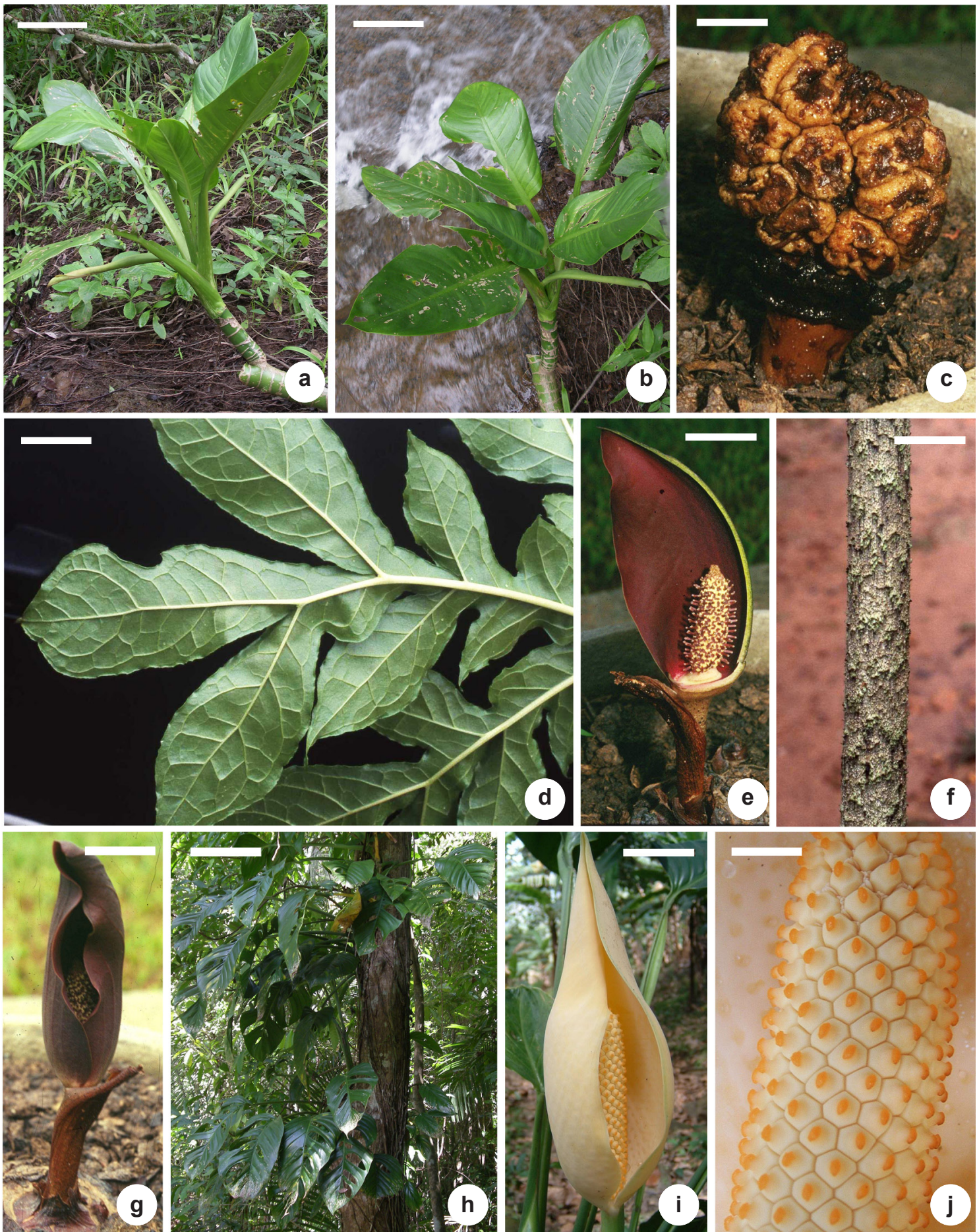

Figure 2 - a-b. Dieffenbachia aglaonematifolia - a. habit in side view, showing post-floral inflorescences; b. habit from above with post-floral inflorescence. c-g. Dracontium nivosum - c. infructescence; d. leaf blade segments, abaxial surface; e. inflorescence in flower with one side of spathe removed; f. petiole, lower part, showing scabrous surface; g. inflorescence in flower viewed ventrally showing spathe gape. $\mathrm{h}-\mathrm{j}$. Monstera adansonii var. klotzschiana - h. habit of mature plant on tree bole; i. inflorescence at female anthesis; $j$. same as i, in close-up showing elliptic stigmas on shortly conical styles. Scale bars: $\mathrm{a}=10 \mathrm{~cm} ; \mathrm{b}=9 \mathrm{~cm} ; \mathrm{c}=1.7 \mathrm{~cm} ; \mathrm{d}=2.5 \mathrm{~cm} ; \mathrm{e}=4.4 \mathrm{~cm} ; \mathrm{f}=2.5 \mathrm{~cm} ; \mathrm{g}$ $=4 \mathrm{~cm} ; \mathrm{h}=30 \mathrm{~cm} ; \mathrm{i}=6 \mathrm{~cm} ; \mathrm{j}=1 \mathrm{~cm}$. 
spathe; flowers unisexual, lacking perigone, female flowers widely spaced, ovary 2-locular, staminodes $3-5$ in whorl, each one $0.2-0.3 \mathrm{~cm}$ long, ovule 1 per locule, whitish, $0.1 \mathrm{~cm}$ long, male flower a polygonal, 4-6-sided synandrium with 4-5 anthers. Berry $0.6 \times 0.4 \mathrm{~cm}$, colour not recorded.

Selected material: Ubajara, T.A. Ribeiro \& I.M. Andrade 44 (HUVA).

The species preliminary conservation status assessment within Ceará is Data Deficient. Only known from a single locality. It occurs in the following Montane forest area: Ibiapaba. The species common name is aninga.

\section{Dracontium L.}

4.1 Dracontium nivosum (Lem.) G.H. Zhu in Govaerts, R.H.A. \& Frodin, D.G. et al., World Checklist Bibliogr. Araceae 301. 2002. Gonçalves \& Lorenzi (2007: 125, 175), (2011: 155, 212, 224)

Fig. 2c-g

Robust geophyte of medium to large stature. Stem a hemispheric tuber, ca. $12 \mathrm{~cm}$ diam., lower side rounded and without roots, upper side \pm flattened and bearing roots and a few tubercles, leaf solitary. Petiole ca. 1.5-2 m long, basal part ca. $2.5 \mathrm{~cm}$ diam., silvery and slightly greenish, densely scabrous with very short protuberances shaped as downwardly curved prickles and arranged in irregular transverse to oblique zones, minutely verruculose in between the zones of protuberances, central and apical parts of petiole ca. 1.5-1.2 cm diam., with protuberance zones more distant from each other, alternating with smoother zones which vary in colour from purplish to silvery, in apical part of petiole the purple zone predominating and alternating with smaller white patches, petiole inconspicuously and shortly geniculate at apex and at junctions with the three primary axes of the blade. Leaf blade ca. $1.0 \mathrm{~m}$ long, 1-1.5 m wide, dracontioid (umbrellalike in overall shape, divided into three \pm equal major segments each of which is further highly subdivided), terminal lobes $8-13 \times 4.5-5.5 \mathrm{~cm}$, ovate to obovate, acuminate, adaxially dark green, with venation (midrib, primary and secondary lateral veins) etched into the surface and margins shortly undulate, abaxially slightly paler, midrib whitish and prominent, primary lateral veins paler than blade, prominent, frequently forming prominent, arching infra-marginal veins on each side. Inflorescence: peduncle ca. $2 \mathrm{~cm}$ diam., mostly subterranean, at least $25 \mathrm{~cm}$ long when in fruit, when in flower ca. $7.5 \mathrm{~cm}$ long and hidden by a brownish cataphyll; spathe ca. $19 \mathrm{~cm}$ long, fornicate, much longer than spadix, convolute in basal quarter and somewhat gaping in upper three quarters forming a narrow opening with \pm undulate margins, leaving the upper part of the spadix visible but not fully exposed, externally purplish-brown, internally almost entirely reddish to dark purple, with a narrow white ring at extreme base at the junction with spadix stipe; spadix (at female anthesis) ca. $7 \times 2 \mathrm{~cm} ., \pm$ cylindric, with a short zone of atrophied flowers at the apex, stipe ca. $0.5 \mathrm{~cm}$ long, whitish; flowers bisexual, perigoniate, tepals free, purple, anthers pale yellow, style purple, projecting 5-6 $\mathrm{mm}$ beyond tepals, stigma whitish, shallowly lobed, no wider than the style. Infructescence subglobose, ca. 6 cm diam.; submature berries ca. $1.5 \mathrm{~cm}$ diam., obpyramidal, pale brown, darker at the apex.

Selected material: Viçosa do Ceará, 4.III.2002, I.M. Andrade et al. 627 (EAC). Tianguá, 6.III.2002, I.M. Andrade et al. 631 (EAC).

The species preliminary conservation status assessment within Ceará is Extent of Occurrence: Endangered (EN); Area of Occupancy: Endangered (EN). Based on 4 specimens from 4 localities. Although the number of records is low, this species was only recorded from Ceará for the first time in 2002 and is so far known only from the area near Viçosa do Ceará and Tianguá in the northern part of the Chapada do Ibiapaba. It also tends to grow in populations of only a few individuals. It occurs in the following Montane forest area: Ibiapaba. Humid forest in the northern part of the Chapada do Ibiapaba and otherwise known only from the states of Pará and Maranhão. The identification of this material as D. nivosum is based mainly on its elongated style, fornicate spathe lacking a distinct tube, short peduncle and geographical location adjacent to existing records for the species and extending its range eastwards (Zhu \& Croat 2004). The species common names are tajá de cobra, jararaca-tajá (Zhu \& Croat 2004: 640).

\section{Lemna L.}

5.1 Lemna aequinoctialis Welw., Ann. Conselho Ultram. 55: 578. 1859. Pott \& Cervi (1999: Figs. 12-18, 78).

Fig. $3 g$

Very small aquatic plant floating on the water surface. Plant body a single undifferentiated thallus, not differentiated into stem and leaves. 


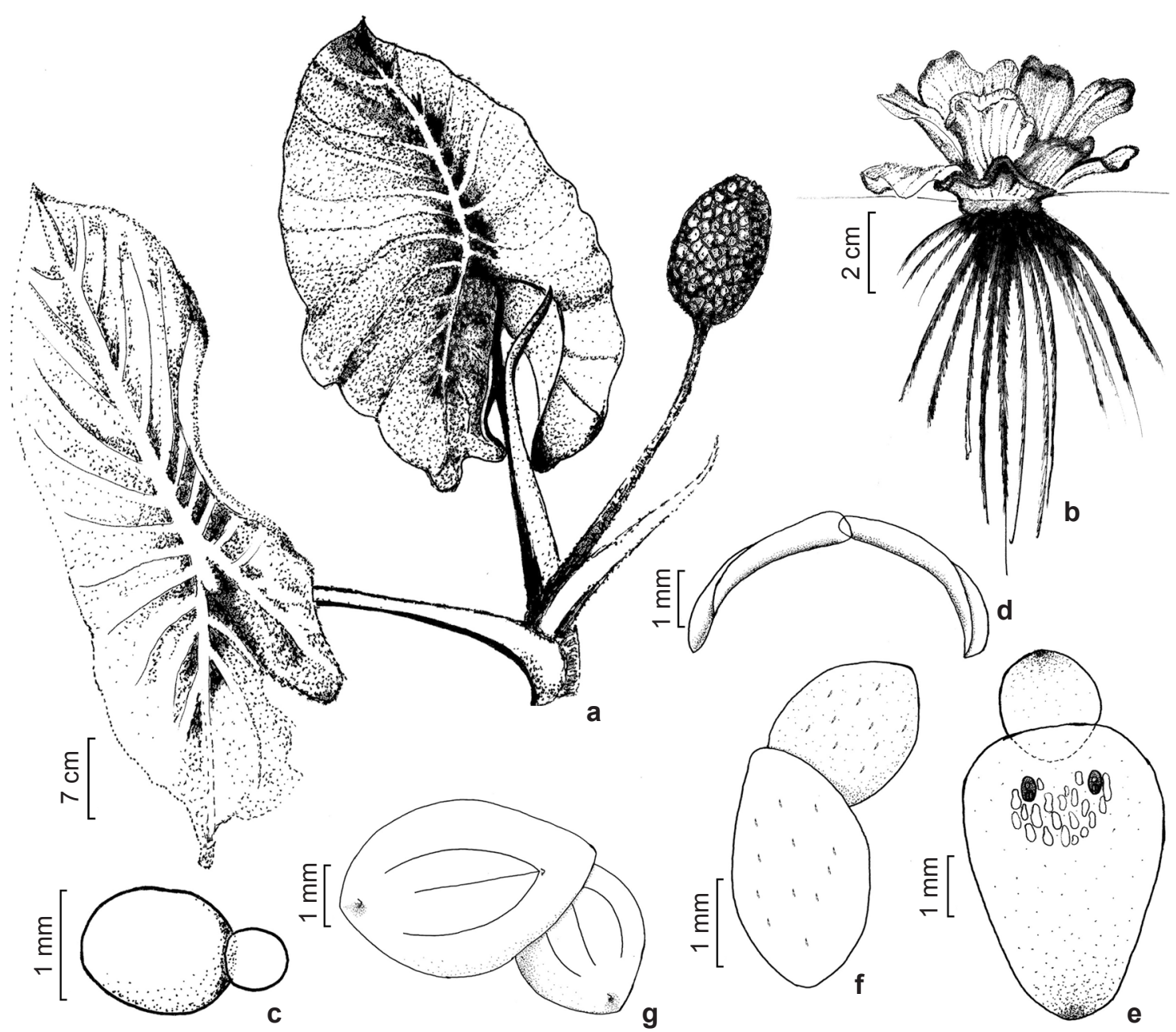

Figure 3 - a. Montrichardia linifera (Sousa 88) - apical part of shoot with infructescence. b. Pistia stratiotes (Normando 196) - habit. c. Wolffia columbiana (Normando EAC 47489) - habit. d-e. Wolffiella welwitschii (Sousa 113 ) - d. habit, e. frond with two flowers on adaxial surface. f. Lemna minuta (Rocha-Neto EAC 31351) - frond without veins on adaxial surface. g. Lemna aequinoctialis (Normando 496), frond with three veins on adaxial surface.

Root 1 per frond, ca. $20 \mathrm{~mm}$ long. Fronds in groups of 3-4, ovate to rounded, 3.5-5 × 1.5-3.5 $\mathrm{mm}$, adaxially with two papillae, one distal and one proximal, and with shining, translucent punctations on both surfaces, veins 3. Flowers not observed (described by Pott \& Cervi (1999) as follows: Flower surrounded by a laterally open prophyll, lacking raphides; stamens of unequal size, $0.42-0.95 \mathrm{~mm}$ long; ovary $0.37-0.65 \times$ $0.12-0.18 \mathrm{~mm}$. Fruit $0.37-0.45 \times 0.25-0.3 \mathrm{~mm}$; seed $0.35-0.4 \times 0.2-0.28 \mathrm{~mm}$, chestnut brown, with 8-26 longitudinal costae).

Selected material: Iguatu, 15.V.2010, L.R.O. Normando 493 (EAC).
The species preliminary conservation status assessment within Ceará is Data Deficient. Only known from a single locality in shallow temporary pond in a rural area. Lemna aequinoctialis is easily distinguished from L. minuta by the presence of three veins and the two papillae on the adaxial surface of the frond, which are present either apically, basally or in both places. Lemna aequinoctialis occurs in the continental America in tropical and subtropical regions, usually in association with various other free-floating species (Landolt 1999). Pott \& Cervi (1999) recorded it in all subregions of the Pantanal, especially in areas of human disturbance. 
5.2. Lemna minuta Kunth, in F.W.H.von Humboldt, A.J.A.Bonpland \& C.S.Kunth, Nov. Gen. Sp. 1: 372. 1817.

Fig. $3 f$

Very small aquatic plant floating on the water surface. Plant body a single undifferentiated thallus, not differentiated into stem and leaves. Root 1 per frond, 6.5-7.5 mm long. Fronds in groups of 2, elliptic to obovate, $2-3 \times 0.8-1 \mathrm{~mm}$, lacking veins, shining translucent striae present on both surfaces. Flowers not observed (described by Pott \& Cervi (1999) as follows: Ovary 0.2-0.4 mm long. Fruit exserted, 0.6-0.3 mm, style persistent; seed solitary). Selected material: Fortaleza, 21.III.2002, J. L. Rocha Neto s.n. (EAC).

The species preliminary conservation status assessment within Ceará is Data deficient. Only known from a single locality. Lemna minuta is probably under-collected in Ceará since elsewhere it has been recorded in both natural (Pott \& Cervi 1999) and disturbed habitats (Pômpeu et al. 2008). It is easily recognized in the non-fertile state by the absence of veins in the fronds (Pott \& Cervi 1999). L. minuta is frequent in the Americas, associated with Salvinia minima Baker and Azolla filiculoides Lam. (Landolt 1999).

\section{Monstera Adans.}

6.1 Monstera adansonii Schott, Wiener Zeitschr. Kunst, Lit. Theater \& Mode 1830(4): 1028. 1830. 6.1.1 Monstera adansonii var. klotzschiana (Schott) Madison, Contrib.Gray Herb. Harvard Univ. 207: 40. 1977.

Fig. $2 h-j$

Root climbing hemi-epiphyte of medium to large stature; vegetative and floral tissues containing trichosclereids. Adult stems with internodes 0.2$3.0 \times 0.2-3.0 \mathrm{~cm}$, gradually increasing in diameter, smooth; flagelliform shoots frequently produced with internodes $0.5-18 \times 1.3-0.3 \mathrm{~cm}$, becoming gradually longer and more slender with the leaves reducing successively to cataphylls, often forming terrestrial stoloniferous populations with smaller leaves, leaves distichous. Petiole 17-69 cm long, green with very numerous paler points (?stomata), upper free part adaxially flattened with angled margins and an apical geniculum, sheath green, slightly shorter than petiole, $11-63.5 \mathrm{~cm}$ long, with green persistent margins. Leaf blade nonvariegated, in juvenile climbing phase ca. $11 \times 4$ $\mathrm{cm}$, when mature 40-69 $\times 20-41 \mathrm{~cm}$, broadly ovate, oblong or elliptic, asymmetric, perforations 0-8 on each side of blade, sometimes absent, margins usually remaining entire, apex acute, base usually asymmetric, cuneate to truncate or subcordate. Inflorescences 1-5 in each floral sympodium, each sympodial article terminating in an inflorescence and consisting of two very short internodes $0.3-3$ $\times 0.3-3 \mathrm{~cm}$ bearing cataphylls, the first cataphyll $15-17.5 \times 2.5-3 \mathrm{~cm}$, the second $20.5-26 \times 2.5-3.5$ $\mathrm{cm}$, peduncle shorter than spathe, green; spathe ca. $22 \mathrm{~cm}$ long, ca. $16 \mathrm{~cm}$ wide when open at anthesis, cymbiform, erect, thick, externally cream or greenish-cream, internally paler cream, opening partially at female anthesis in the central part but the apical and basal parts remaining convolute, opening completely at male anthesis with a broadly elliptic gape and at least one margin revolute, becoming completely caducous immediately after flowering; spadix ca. $16 \mathrm{~cm}$ long, ca. $3.7 \mathrm{~cm}$ diam., erect, subcylindric, stout, apex rounded, some basal flowers lacking stamens; flowers bisexual, lacking perigone, gynoecia ca. 5-6 mm diam., distinctly prismatic, pale cream, stylar region somewhat apically narrowed, stigma elliptic, orange-coloured and wet at female anthesis. Berry whitish when submature, seed ca. $1 \times 0.7 \mathrm{~cm}$, dark brown.

Selected material: Maranguape, 16.II.2002, I.M. Andrade et al. 504 (EAC). Pacatuba, 25.II.2003, I.M. Andrade 681 (EAC). São Benedito, 2.III.2002, I.M. Andrade et al. 602 (EAC).

The species preliminary conservation status assessment within Ceará is Extent of Occurrence: Endangered (EN); Area of Occupancy: Vulnerable (VU). Based on 13 specimens from 5 localities. It occurs in the following Montane forest areas: Aratanha, Ibiapaba, Maranguape. This species is a climbing plant which multiplies vegetatively with ease in humid forest habitat. Where it occurs, it tends to be frequent or common, but often survives less conspicuously in disturbed forest as the juvenile form, e.g. over rocks by waterfalls, making it easily overlooked. It probably occurs in more localities within the humid forest fragments of Ceará, but is almost certainly confined to this habitat. The species common names are costelade-adão (BA); imbé (PB, CE).

6.1.2 Monstera adansonii var. laniata (Schott) Madison, Contrib. Gray Herb. Harvard Univ. 207: 38. 1977.

Fig. $4 a, b$

Plant a root-climbing hemi-epiphyte of large stature; vegetative and floral tissues containing trichosclereids. Stem with internodes 0.4-20 $\times$ $3.3-4 \mathrm{~cm}$, leaves (seen in adult plant) distichous. Petiole 43-65.6 cm long, green with minute white 
dots (?stomata), upper free part adaxially flattened with angled margins and apical geniculum, sheath up to $55 \mathrm{~cm}$ long with persistent, green margins. Leaf blade in adult plants ca. 35-57 $\times$ 20.9-32.5 cm, oblong, asymmetric, perforations 0-9 on each side, apex acute, base usually asymmetric, cuneate to truncate, primary lateral veins 14-19 on each side, arching and running into a submarginal collective vein, finer veins parallel to primary laterals. Inflorescence: floral sympodium consisting of a single inflorescence preceded by two cataphylls: first cataphyll (bracteole) 16-21 $\times 2.5-2.8 \mathrm{~cm}$, second cataphyll (mesobracteole) 24-25 × 4-5.3 cm, peduncle 10-22.5 cm long, green; spathe 9.8-16 × 5.7-10 cm, cymbiform, erect, thick, externally cream to greenish-cream, internally paler cream, opening partially at female anthesis in the central part but with apical and basal margins still somewhat convolute, at male anthesis opening wider with a broadly elliptic gape and at least one margin revolute, then becoming completely caducous soon after male anthesis; spadix erect, 7.5-13.2 × 1.3-3.5 cm, subcylindric, stout, apex rounded, some basal flowers lacking stamens; flowers bisexual, lacking perigone, gynoecia distinctly prismatic, 4-5 $\mathrm{mm}$ diam. at anthesis, ca. 4-6 × 4-6 mm in fruit, pale cream, stylar region flattened apically, stigma $2.5-3 \mathrm{~mm}$ long at anthesis, narrowly elliptic. Berries cream at apex with dark brown stigma remains, compressed and sub-hexagonal, white and succulent below.

Selected material: Guaramiranga, 13.II.2003, I.M. Andrade 671 (EAC). Pacoti, 19.II.2002, I.M. Andrade 544 (EAC).

The species preliminary conservation status assessment within Ceará is Extent of Occurrence: Critically Endangered (CR); Critically Endangered (CR). Based on 4 specimens from 3 localities. It occurs in the following Montane forest area: Baturité. All collections known are from one small area of the Serra de Baturité, the earliest having been made in 1910. It is possible that a thorough search of this humid forest area will reveal other populations, but this taxon remains very poorly known in Ceará. The specimens we have studied differ from other Ceará specimens of $M$. adansonii seen in having gynoecia which are flattened at the apex, and for this reason we treat this material provisionally as $M$. adansonii var. laniata Madison's (1977) treatment of the varieties of $M$. adansonii is in need of revision. Lima-Verde \& Gomes (2007) report on material of Monstera (as
M. obliqua) from the Serra de Baturité which may well belong to this taxon. The earliest collection known was made by Ernst Ule, who collected this taxon in the Serra do Baturité in 1910 [probably in the municipality of Guaramiranga, Sep. 1910, E. Ule $9002(\mathrm{~K})]$.

6.2 Monstera praetermissa E.G.Gonç. \& Temponi, Brittonia 56(1): 72. 2004. Gonçalves \& Lorenzi (2007: 223), (2011: 276). Figs. 4c, d

Root-climbing hemi-epiphyte of small to medium stature; vegetative and floral tissues containing trichosclereids. Stem with rather dark green internodes covered with shallow, concolorous, inconspicuous verruculae. Petiole 1.5-10.5 cm long, rather dark green and lacking paler dots, with apical geniculum, petiole sheath rapidly marcescent, turning black-brown and eventually deciduous. Leaf blade when adult 17.5 $39.5(-44.3) \times 4.6-20(-23.2) \mathrm{cm}$, asymmetric, ovate (more strongly symmetric, falcate and lanceolate when juvenile), falcate, coriaceous, perforate, elliptic, margin entire or becoming pinnatifid to pinnatipartite, apex subacute to obtuse, acuminate to cuspidate, base subacute to broadly obtuse, \pm asymmetric, becoming dark brown to black when dried, perforations $(0-) 2-3(-4)$ on the wider side of the blade, \pm elliptic, in a single longitudinal series, often extending across almost the entire half blade from midrib to margin, often reaching margin and breaking through to make the blade partially and deeply pinnatipartite, adaxially \pm dark green, glossy, unvariegated, abaxially paler and \pm glossy, primary lateral veins 5-7 per side, adaxially impressed and concolorous, abaxially prominent and whitish green, joining into an inconspicuous infra-marginal collective vein extending for most of the blade length, finer venation reticulate. Inflorescence 1-3 per floral sympodium, peduncle ca. 8-10 cm long, shorter than petiole, equalling or longer than spadix but not more than twice as long; spathe ca. $6 \mathrm{~cm}$ long, pale yellow or cream; spadix 6-6.5 cm long; flowers bisexual, lacking perigone, gynoecia cream, stylar region truncate apically, stigma linear. Infructescence $7-7.5 \mathrm{~cm}$ long, cylindric, erect, with peduncle \pm patent and bent upwards distally, berries green when immature becoming yellow to intensely yellow at maturity; seeds 5-10 mm long.

Selected material: Guaramiranga, 19.II.2002, I.M. Andrade et al. 547 (EAC). Ibiapina, 1.III.2002, I.M. Andrade et al. 573 (EAC). São Benedito, 22.III.2000, 

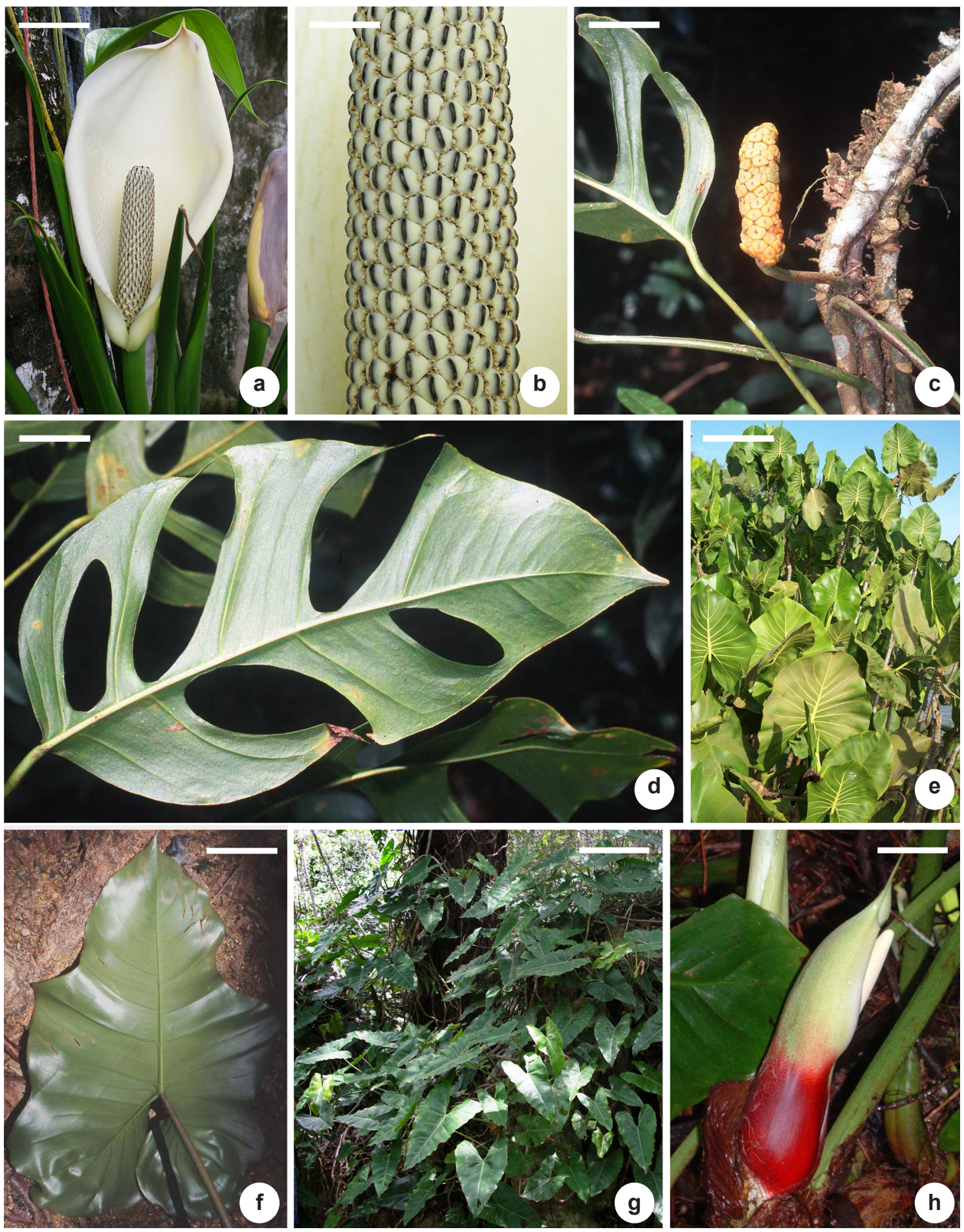

Figure 4 - a-b. Monstera adansonii var. laniata - a. inflorescence at male anthesis; b. spadix in close-up at male anthesis showing linear, subsessile stigmas. c-d. Monstera praetermissa - c. infructescence; d. leaf blade, abaxial surface. e. Montrichardia linifera - population along river margin. f. Philodendron $s p$. aff. ruthianum - leaf blade, abaxial surface. g. Philodendron acutatum - habit of mature plants on rock outcrop and tree bole. h. Philodendron ornatum - inflorescence at anthesis. Scale bars: $\mathrm{a}=5 \mathrm{~cm} ; \mathrm{b}=1 \mathrm{~cm} ; \mathrm{c}=3.3 \mathrm{~cm} ; \mathrm{d}=2.7 \mathrm{~cm} ; \mathrm{e}=18 \mathrm{~cm} ; \mathrm{f}=5 \mathrm{~cm} ; \mathrm{g}$ $=26 \mathrm{~cm} ; \mathrm{h}=2.8 \mathrm{~cm}$. 
E.B. Sousa et al. 402 (EAC). Ubajara, 25.XII.1999, A. Fernandes et al. (EAC).

The species preliminary conservation status assessment within Ceará is Extent of Occurrence: Endangered (EN); Area of Occupancy: Near Threatened (NT). Based on 7 specimens from 5 localities. It occurs in the following Montane forest areas: Baturité, Ibiapaba. A climbing plant restricted to humid forest habitat within which it readily multiplies vegetatively.

\section{Montrichardia H. Crüger}

7.1 Montrichardia linifera (Arruda) Schott, Arac. Betreff. 1: 5. 1854. Souza \& Lorenzi (2005: 96).

Figs. 3a, 4e

Robust arborescent helophyte, with conspicuous, erect, epigeal stems multiplying vegetatively from hidden, hypogeal rhizomes and forming large colonies along rivers and streams. Erect stems to $4 \mathrm{~m}$ tall, branching sympodially near the apex after the first flowering, internodes welldeveloped $0.2-27 \times 2-36.8 \mathrm{~cm}$, green near stem apex, becoming grey and sometimes tuberculate to shortly aculeate at the base, leaves crowded together in a rosulate terminal cluster with the rest of the stem leafless, with the petiole \pm patent and bent upwards at the apex so that the blade is held \pm vertically. Petiole $16.5-46 \mathrm{~cm}$ long, lacking apical geniculum, sheath 9-26 cm long, with apical ligule $0.5-7 \mathrm{~cm}$ long, soon marcescent turning brown and later decomposing. Leaf blade 15.1-45 $\times 15-39 \mathrm{~cm}$, cordate to sagittate, adaxially green with main veins concolorous, abaxially hardly paler with main veins whitish, anterior division a little longer than posterior divisions, apex (subacute to) obtuse and then (acuminate to) cuspidate, posterior divisions usually separated by a deep (sometimes broad) parabolic to linear sinus, or overlapping and without a sinus; primary lateral veins forming a slender infra-marginal collective vein, those of the anterior division 4-6(-7) on each side, acroscopic veins of each posterior division 3-4, basicopic ones $0-3(-4)$ and much more slender, basal ribs well developed, fine venation \pm reticulate, arising from the primaries at a relatively acute angle and usually forming a slender interprimary collective vein running between each pair of primaries. Inflorescence terminal, 1-2 in each floral sympodium, the succeeding shoot article arising in the axil of the second leaf below the spathe, peduncle 5.3-11.0 cm long, erect in flower and fruit, green; spathe $17-28 \mathrm{~cm}$ long, erect, slightly constricted between tube and blade, entirely deciduous after anthesis, tube $5 \mathrm{~cm}$ long, externally green, often with a reddish tinge, \pm glossy, internally vinaceous at base, blade ca. $23 \mathrm{~cm}$ long, cymbiform, externally yellowish green, internally cream-white; spadix 17-23 cm long; female zone ca. $3.5 \mathrm{~cm}$ long, greenish-yellow, male zone ca. 19 cm long, thicker than female zone, whitish-cream; flowers unisexual, lacking perigone, male flower: stamens (3-)4-5(-6), apically truncate, 0.4-0.5 $\times$ 0.3-0.6 cm, anthers sessile, female flower: gynoecium prismatic-cylindric, ovary 1-locular, ovules 1-2, anatropous, funicle short, placenta basal, stigma small on shallowly elevated central area. Infructescence 9-10 × 5-6 cm diam., robust, subcylindric to subglobose; berry green when immature, prismatic basally, dried brown stigma large and rugose; seeds 1.9-2.3 cm long, 1-1.6 $\mathrm{cm}$ wide, brown.

Selected material: Caucaia, 21.I.2006, fl., A. S. F. Castro 1675 (EAC). Granja, 11.X.2007, L.Q. Matias 526 (EAC). São Gonçalo do Amarante, 7.VI.2008, M.F. Moro et al. 397 (EAC).

The species preliminary conservation status assessment within Ceará is Extent of Occurrence: Endangered (EN); Area of Occupancy: Vulnerable (VU). Based on 5 specimens from 4 localities. This species is very probably more widespread in aquatic habitats of the littoral region of Ceará than the current records indicate, making it unlikely to be endangered. Montrichardia linifera occurs along the margins of permanent ponds and lakes and along the flooded muddy banks of rivers and streams where it can form large populations. A recent study of leaf shape variation was carried out by Silva et al. (2012) in the neighbouring state of Piauí. The genus occurs only in the Neotropics (Cook 1996; Mayo et al.1997).

\section{Philodendron Schott}

8.1 Philodendron acutatum Schott, Syn. Aroid. 94. 1856. Maia et al. (2010: Fig. 1). Fig. 4g

Root-climbing hemi-epiphyte or lithophyte of medium stature. Stem epigeal, lacking milky sap, internodes to $12-13 \mathrm{~cm}$ long or more, green to purplish-tinged and \pm glaucous at shoot tip, becoming straw-coloured when older, prophyll caducous, abaxially green with small purple spots (extra-floral nectaries), adaxially whitish rose-coloured. Petiole 21-30 cm long, green with inconspicuous whitish striae, subterete to terete, with scattered purple extra-floral nectaries denser 
towards apex, lacking apical geniculum. Leaf blade 23-40 × 13-19 cm, sagittate, adaxially dark green and glossy, abaxially paler and glossy, posterior divisions obtuse to rounded, separated by a linear to spathulate sinus hardly or not denuded near petiole junction; primary lateral veins 3-5 on each side of the anterior division, adaxially impressed and slightly paler than blade, not forming inframarginal collective vein, interprimary veins usually present, in each posterior division acroscopic veins $2-3$, basiscopic veins $0-1$, forming straight basal rib, fine venation parallel to primaries. Inflorescences 1-2 per floral sympodium, peduncle $9 \mathrm{~cm}$ long, shorter than spathe; spathe $12-16 \mathrm{~cm}$ long, externally matte green, internally upper half white and lacking resin canals, lower half covered with distinctive yellow longitudinal resin canals and reddish-purple towards base, post-floral spathe externally yellowish green in upper half; spadix $10 \mathrm{~cm}$ long, female zone green, $3.5 \mathrm{~cm}$ long, intermediate sterile zone ca. $0.5 \mathrm{~cm}$ long, stouter than female zone, white, male zone ca. $5 \mathrm{~cm}$ long, subcylindric, white; flowers unisexual, lacking perigone, ovary white, stigma greenish. Berries not observed.

Selected material: Caucaia, 27.V.1998, E.B. Souza s.n. (EAC 26584). Choró, 6.V.1997, M.A. Figueiredo-s.n. (EAC 25492). Crato, 11.VIII.1993, A. Figueiredo \& M. Mata (EAC 20057). Fortaleza, 11.XI.1992, F.S. Araújo (EAC 21487). General Sampaio, 30.V.2007, M.F. Moro et al. 139 (EAC). Ibiapina, 1.III.2002, I.M. Andrade et al. 576 (EAC). Maranguape, 16.II.2002, I.M. Andrade et al. 515 (EAC). Pacatuba, 17.II.2002, I.M. Andrade et al. 523 (EAC). Santa Quitéria, 8.V.1997, L.W. LimaVerde(EAC 25538). São Benedito, 2.II.2002, I.M. Andrade et al. 618 (EAC, HUEFS). São Gonçalo do Amarante, 30.VII.2010, A.S.F. Castro 2347 (EAC). Ubajara, 8.V.1997, L.W. Lima-Verdes (EAC 25538). Uruburetama, 21.II.2002, I.M. Andrade 552 (EAC). Viçosa do Ceará, 4.III.2002, I.M. Andrade et al. 626 (EAC).

The species preliminary conservation status assessment within Ceará is Extent of Occurrence: Least Concern (LC); Area of Occupancy: Least Concern (LC). Based on 17 specimens from 16 localities. It occurs in the following Montane forest areas: Araripe, Aratanha, Ibiapaba, Maranguape, Uruburetama. Philodendron acutatum has a wide ecological range, occurring both in humid forest, seasonal and dry forest and caatinga, especially on rock outcrops. This species has been widely identified as $P$. imbe Schott ex Kunth, but this name is now thought to apply to a rare taxon endemic to Rio de Janeiro state (Mayo \& Sakuragui 2011).
8.2 Philodendron ornatum Schott in Oesterr. bot. Wochenbl. 3: 378. $1853 . \quad$ Figs. 4h, 5a,b

Root-climbing hemi-epiphyte of medium to large stature. Stem epigeal, lacking milky sap, juvenile internodes slender, elongated, prophylls caducous, mature internodes much shorter and thicker, covered by brown persistent, net-fibrous prophylls, mature leaves borne in rosulate crown. Petiole $24-86 \mathrm{~cm}$ long, adaxially raised centrally (at least apically), abaxially rounded, rugose to verruculose and reddish purple at apex, verrucae arranged in longitudinal rows, becoming smoother and greener towards the base, lacking apical geniculum. Leaf blade: juvenile leaves ovate, long-acuminate apically and obtuse to truncate at base, with long petiole sheaths; adult leaf blade ca. 24-85 × 17-62 cm, cordate, coriaceous, adaxially dark green, abaxially paler, apex cuspidate; anterior division up to $67 \mathrm{~cm}$ long, $62 \mathrm{~cm}$ wide, primary lateral veins $10-12$ on each side, impressed above and prominent below, producing conspicuous secondaries on both sides distally, interprimary veins well-developed; each posterior division up to $19 \mathrm{~cm}$ long, $28 \mathrm{~cm}$ wide, acroscopic veins $4-5$, basiscopic veins ca. 5 , basal rib denuded for up to $8-9 \mathrm{~cm}$, sinus between posterior divisions broadly spathulate to reniform, fine venation parallel to primary lateral veins. Inflorescence: peduncle $6-8$ $\mathrm{cm}$ long, green with conspicuous white striae and dots in upper part; spathe $15-16 \mathrm{~cm}$ long, internally lacking conspicuous resin canals, long-rostrate, tube ca. $6 \mathrm{~cm}$ long, $2.3 \mathrm{~cm}$ diam., externally green and minutely white-dotted, blade ca. $9.5 \mathrm{~cm}$ long, externally white, internally white; spadix sessile, $11.3 \mathrm{~cm}$ long, female zone ca. $2 \mathrm{~cm}$ long, sterile zone ca. $2 \mathrm{~cm}$ long, thicker than female zone at proximally, tapering distally, male zone ca. $7 \mathrm{~cm}$ long, ellipsoid-cylindric; flowers unisexual, lacking perigon, ovary 4-5-locular, ovules numerous, placentation axile. Fruits not seen.

Selected material: Guaramiranga, 19.II.2002, I.M. Andrade et al. 536 (EAC). Ibiapina, 1.III.2002, I.M. Andrade et al. 575 (EAC). Maranguape, 16.II.2002, I.M. Andrade et al. 512 (EAC). Pacatuba, 25.II.2003, I.M. Andrade 683 (EAC). Pacoti, 19.II.2002, I.M. Andrade et al. 535 (EAC). São Benedito, 2.III.2002, I.M. Andrade et al. 620 (EAC). Ubajara, 24.IX.1998. A. Fernandes \& E.P. Nunes (EAC 28491).

The species preliminary conservation status assessment within Ceará is Extent of Occurrence: Vulnerable (VU); Area of Occupancy: Near Threatened (NT). Based on 14 specimens from 10 localities. It occurs in the following Montane forest 

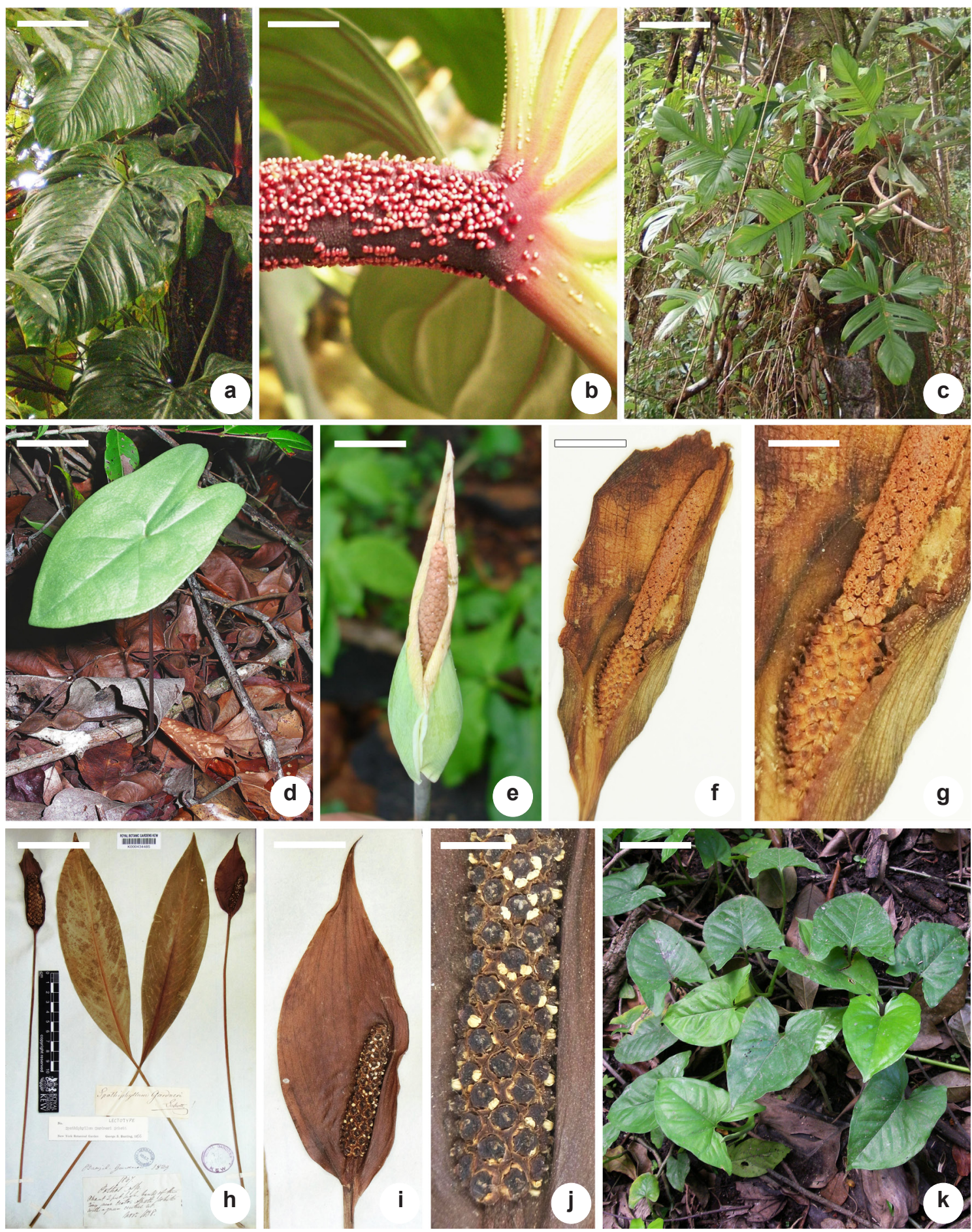

Figure 5 - a-b. Philodendron ornatum - a. leaf blades of mature hemi-epiphytic plant; b. petiole apex showing verrucose surface. c. Philodendron pedatum - habit on tree bole. d-g. Scaphispatha gracilis - d. leaf; e. post-floral inflorescence; f. inflorescence at recent post-male anthesis; g. same as f in close-up. h-j. Spathiphyllum gardneri-h. leaves, inflorescence and infructescence of type specimen; i. inflorescence; j. spadix in close-up showing perigoniate flowers. k. Syngonium vellozianum - habit of juvenile terrestrial plants. Scale bars: a = $19 \mathrm{~cm} ; \mathrm{b}=0.6 \mathrm{~cm} ; \mathrm{c}=22 \mathrm{~cm}$; $\mathrm{d}=2.5 \mathrm{~cm} ; \mathrm{e}=1.2 \mathrm{~cm} ; \mathrm{f}=0.7 \mathrm{~cm} ; \mathrm{g}=0.3 \mathrm{~cm} ; \mathrm{h}=7 \mathrm{~cm} ; \mathrm{i}=2 \mathrm{~cm} ; \mathrm{j}=0.6 \mathrm{~cm} ; \mathrm{k}=7.5 \mathrm{~cm}$. 
areas: Aratanha, Baturité, Ibiapaba, Maranguape. This hemi-epiphytic species is restricted to humid forest habitat and typically has a patchy distribution within it, needing large tree boles to reach full mature size.

8.3 Philodendron pedatum (Hook.) Kunth, Enum. pl. 3: 49. 1841.Gonçalves \& Lorenzi (2007: 88), (2011: 111, 506a).

Fig. 5c

Root-climbing hemi-epiphyte of medium stature. Stem epigeal, lacking milky sap, internodes elongated, up to $17 \mathrm{~cm}$ long or more in juvenile shoots, becoming shorter and up to $3 \mathrm{~cm}$ diam. in flowering shoots, pale brown to straw-coloured. Petiole 30-47 cm long, cylindric, often subterete and shallowly triangular adaxially with rounded central ridge and margins, usually rugulose to subverruculose, dark green with whitish striae and small reddish spots (extra-floral nectaries) denser towards the apex, lacking apical geniculum. Leaf blade tripartite when juvenile, the anterior division with an ovate, acuminate apical lobe and a lateral linear-falcate lobe on each side, the two posterior divisions simple, asymmetrically lanceolate and falcate; adult blades 30-62 × 34-64 $\mathrm{cm}$, pinnatifid-hastate, the anterior and posterior divisions deeply separated from each other and each deeply pinnatifid, adaxially dark green, glossy, abaxially paler, major veins impressed adaxially and prominent abaxially; anterior division: apical lobe ovate to rhombic with obtuse to cuspidate apex, lateral lobes 2-3 on each side, oblong, each with acute asymmetric apex or sometimes each lobe itself shallowly 2-3-lobed, primary lateral veins 2-3 per lateral lobe; posterior divisions: patent with rather irregular lobing, sinus narrow, linear to spathulate, apex obtuse to rounded, major veins forming straight well-developed basal ribs, each division with 1-2 acroscopic lobes each with 1-3 primary veins, and 2 basiscopic lobes each with 2-3 primary veins, finer veins parallel to primaries. Inflorescences $1-2(-4)$ per floral sympodium, peduncle 5-7 cm long in flower, lengthening after anthesis, with white striations and purple spots; spathe in flower 11-12 cm long, externally somewhat glaucous green with scattered vinaceous spots (extra-floral nectaries), tube $5 \mathrm{~cm}$ long, about as long as blade, internally pinkish-red at base, blade internally whitish-green with white dots, post-floral spathes larger, ca. $16 \mathrm{~cm}$ long; spadix $11 \mathrm{~cm}$ long, exuding orange resin from male and sterile zones during anthesis, female zone
$3.5 \times 1.0 \mathrm{~cm}$, green, intermediate sterile zone ca. $0.7 \times 1.3 \mathrm{~cm}$, white, thicker than female or male zones, male zone ca. $6.5 \times 1.2 \mathrm{~cm}$, cream coloured, subcylindric to slightly clavate; flowers unisexual, lacking perigone, ovary green, 6-7 locular, ovules ca. 2 per locule, placentation axile.

Selected material: Fortaleza, 15.IV.1994, L.W. LimaVerde (EAC 21126). Guaramiranga, 19.II.2002, I.M. Andrade 539 (EAC). Pacatuba, 17.II.2002, I.M. Andrade et al. 524 (EAC, HUEFS). Pacoti, 18.II.2002, I.M. Andrade et al. 527 (EAC).

The species preliminary conservation status assessment within Ceará is Extent of Occurrence: Endangered (EN); Area of Occupancy: Endangered (EN). Based on 10 specimens from 9 localities. It occurs in the followng Montane forest areas: Aratanha, Baturité. This hemi-epiphytic species is widespread and very variable within the neotropics as a whole. In Ceará it is so far recorded only in two neighbouring humid forest areas, but it is likely that it will be found in other such areas in the state. The leaf division is variable between populations and changes considerably as the plant grows from juvenile to adult.

8.4 Philodendron sp. aff. ruthianum Nadruz, Bol. Mus.Biol. Mello Leitão (N.Sér.) 28: 37. 2011.

Fig. $4 f$

Root-climbing hemi-epiphyte of medium stature. Stem epigeal, lacking milky sap, internodes soon turning pale brown, prophyll ca. $3 / 4$ as long as petiole, whitish with a tinge of yellow and rose. Petiole $20-27.5 \mathrm{~cm}$ long, \pm cylindric, green, adaxially flattened, lacking apical geniculum. Leaf blade $20-28 \times 12.5-19.5 \mathrm{~cm}$, panduriformsagittate, adaxially glossy dark green, abaxially a little paler, anterior division with broadly ovate apical lobe, margins strongly sinuate to form a single broad, shallow rounded lateral lobe on each side, posterior divisions broad and rounded, partially overlapping or not, sinus linear to spathulate, each posterior division denuded only very near the petiole junction, primary lateral veins 4-5 on each side of the anterior division, adaxially impressed, abaxially prominent, concolorous on both sides, interprimary veins frequently present, each posterior division with 3-4 acroscopic veins and 4-5(-6) basiscopic veins, forming a straight basal rib, basiscopic lamina area of posterior divisions broad and well developed, finer veins parallel to primaries. Inflorescence not observed. Selected material: Pacatuba, 17.II.2002, I.M. Andrade et al. 526 (EAC, HUEFS). 
The species preliminary conservation status assessment within Ceará is Data Deficient. Only known from a single locality. It occuros in the following Montane forest area: Aratanha. The plant collected in Ceará is named here provisionally as $P$. sp. aff. ruthianum Nadruz. It differs from $P$. ruthianum, a species endemic to Espírito Santo (Coelho 2011) in the broader, overlapping posterior divisions and primary lateral veins concolorous on both surfaces. It also should be compared with P. nadruzianum Sakur. (Sakuragui 2012). Fertile material of the Ceará plant is needed for a more complete determination.

\section{Pistia L.}

9.1 Pistia stratiotes L., Spec. Pl. 963. 1753. Souza \& Lorenzi (2005: 96); Gonçalves \& Lorenzi (2007: 151, 364), (2011: 190, 448).

Fig. 3b

Aquatic plant free-floating on the water surface, densely covered with conspicuous hairs. Stem of each leafy plant very abbreviated, producing relatively long stolons 2.5-14-0.7-0.8 $\mathrm{cm}$; roots very conspicuous and numerous, usually suspended in the water, feathery and very densely branched. Leaves densely rosulate, several to numerous, petiole only weakly differentiated. Leaf blade subsessile, 2.4-11-1.6-7.0 cm, wedgeshaped, broadest at apex then narrowing somewhat towards base, also sometimes obovate to broadly elliptic, apex rounded to truncate, base cuneate; primary veins $5-7$, longitudinal, subparallel, adaxially sulcate, abaxially costate, very prominent. Inflorescence 1 per subtending leaf, very small; spathe whitish green, $0.5-1 \mathrm{~cm}$ long; flowers unisexual, lacking perigone, female flower a single gynoecium, ovary ovoid, style ca. $0.2 \mathrm{~cm}$ long, stigma $0.1 \mathrm{~cm}$ wide, male flowers forming a whorl of fused stamens. Fruit a thin-walled berry.

Selected material: Aiuaba, 08.VI.1996, L.W. Lima-Verde et al. 297 (EAC). Caucaia, 12.III.2000, L.Q. Matias s.n. (EAC 29046). Icó, 8.III.1936, P. von Luetzelburg 26838 (IPA). Iguatu, 5.IX.2009, L.Q. Matias 590 \& L.R.O. Normando (EAC). Varjota, 24.V.2011, J.R.A. Paiva \& L.Q. Matias 18 (EAC). São Gonçalo, 28.VII.2010, A.S.F. Castro 335 (EAC).

The species preliminary conservation status assessment within Ceará is Extent of Occurrence: Least Concern (LC); Area of Occupancy: Least Concern (LC). Based on 9 specimens from 9 localities. Although only rather few collections have been made in Ceará, this species is commonly observed in perennial and temporary aquatic habitats, including small ponds and large reservoirs; it forms especially large conspicuous populations in eutrophicated lakes and other kinds of disturbed aquatic habitat. Pistia stratiotes has a pantropical distribution (Cook 1996; Mayo et al. 1997).

\section{Scaphispatha Brongn. ex Schott}

10.1 Scaphispatha gracilis Brongn. ex Schott, Prodr. Syst. Aroid. 214. 1860. Gonçalves \& Lorenzi (2007: 107), (2011: 133).

Fig. 5d-g

Geophytic herb to $50 \mathrm{~cm}$ tall, leaves appearing after the inflorescence. Stem a hypogeal, globose tuber ca. $2 \mathrm{~cm}$ diam. Petiole $16-42.5 \mathrm{~cm}$ long, rather slender, green with darker green striae and dots, lacking apical geniculum. Leaf blade peltatecordate to peltate-sagittate, $9.9-18 \mathrm{~cm}$ long, 5.6$12.9 \mathrm{~cm}$ wide, widest across the posterior lobes, not variegated, adaxially bright green, abaxially paler, apex obtuse and cuspidate to acute-acuminate, posterior lobes distally rounded separated by a parabolic sinus, primary lateral veins $2-3$ on each side of the anterior lobe, $1-2$ on acroscopic side of basal ribs of posterior lobes, all joined into a distinct infra-marginal vein running from basal ribs to leaf apex, with a second external submarginal vein also usually visible, secondary and tertiary lateral veins arising from the primaries at a wide angle and joining into a sinuose or zig-zag interprimary collective vein between each pair of primary lateral veins. Inflorescence solitary, erect, peduncle 30-40 $\mathrm{cm}$ long, slender, $0.25-0.3 \mathrm{~cm}$ diam; spathe 5-6 cm long, bright green externally and white internally; spadix ca. 2.5-3 cm long, female zone ca. $1 \mathrm{~cm}$ long, male zone ca. $1.9 \mathrm{~cm}$ long, contiguous with female zone or separated by a very few sterile male flowers; flowers unisexual, lacking perigon, male flower a synandrium of several connate stamens, anthers opening by \pm rounded pores, stigma small on narrow projecting style. Fruits not seen.

Selected material: Viçosa do Ceará, 4.III.2002. I.M. Andrade et al. 622 (EAC). Crato, XI.1976, J. Bogner 1211 (K, L, M); Crato, 28.X.1934, P. Luetzelburg 25984 (not seen, M, US). Crateus, 27.II.2000, L.W. Lima-Verde 1068 (EAC).

The species preliminary conservation status assessment within Ceará is Extent of Occurrence: Vulnerable (VU); Area of Occupancy: Least Concern (LC). Based on 6 specimens from 3 localities. It occurs in the following Montane forest areas: Araripe, Ibiapaba. In the population seen by us near Lajes (municipality of Viçosa do Ceará) the plants occurred dispersed in shady spots in secondary scrub probably derived from seasonal forest. Bogner (1980) and Gonçalves (2005) have previously described this species from Ceará. 
11. Spathicarpa W.J.Hooker

11.1 Spathicarpa gardneri Schott in Bonplandia 6: 124. 1858. Figs.: Souza \& Lorenzi (2005: 97). Gonçalves \& Lorenzi (2007: 235), (2011: 290).

Geophytic herb to ca. $20 \mathrm{~cm}$ tall. Stem a tuber $1.5 \mathrm{~cm}$ diam. Leaves $1-4$, semi-erect to prostrate on the ground. Petiole 7-23 cm long, cylindric or adaxially slightly flattened, sheathed basally. Leaf blade ca. 6-12 × 3.0-8.0 cm, lanceolate- to ovateemarginate, cordate, sagittate or subhastate, apex acute-acuminate to cuspidate, membranaceous, adaxially glossy mid-green and often variegated with irregular grey-green patches, major veins slightly impressed, abaxially glossy, paler and greyish, major veins prominent, fine venation reticulate. Inflorescence solitary per leafy shoot, peduncle slender, $13.5-35 \mathrm{~cm}$ long, distinctly longer than leaves; spathe $4-4.8 \mathrm{~cm}$ long, ca. $0.6 \mathrm{~cm}$ wide, narrowly elliptic to oblanceolate, pale green; spadix entirely adnate to and somewhat shorter than spathe; flowers unisexual, lacking perigone, female flowers in two external rows with male flowers in two internal parallel rows, male flower a stipitate synandrium with a cushion-like glandular central connective, female flower consisting of a single ovoid gynoecium surrounded by 3 much shorter, umbonate green staminodes. Fruit not observed.

Selected material: Aiuaba, 21.III.1991, M.A. Figueiredo et al. 19 (EAC). Brejo Grande, II.1839, G. Gardner 2447 (K, holotype). Cariri Cearense, 25.III.1936, $P$. Luetzelburg 25977 (IPA). Capistrano, 30.V.1994, L.W. Lima-Verde (EAC 21527). Choró, 5.V.1997, L.W. Lima-Verde (EAC 25512). Crateus, 21.V.1997, M.A. Figueiredo et al. (EAC 25847). Ipu, 6.IV.2001, E.G. Gonçalves et al. 836 (K). Viçosa do Ceará, 4.III.2002, I.M. Andrade et al. 630 (EAC). Tianguá, 6.III.2002, I.M. Andrade et al. 637 (HUEFS). Ubajara, 28.I.1968, D. Andrade- Lima 68-5195 (IPA).

The species preliminary conservation status assessment within Ceará is Extent of Occurrence: Least Concern (LC); Area of Occupancy: Least Concern (LC). Based on 14 specimens from 10 localities. It occurs in the following Montane forest areas: Araripe, Ibiapaba. This species common name is flor de cobra $(\mathrm{CE})$.

\section{Spathiphyllum Schott}

12.1 Spathiphyllum gardneri Schott Aroideae 1: 2. 1853 . Fig. $5 h-j$

Terrestrial herb to ca. $60 \mathrm{~cm}$, probably rhizomatous. Stem inconspicuous, plant appearing acaulescent, internodes not visible. Petiole shorter than peduncle, ca. $20 \mathrm{~cm}$ long or more, apical geniculum ca. $2 \mathrm{~cm}$ long. Leaf blade 24.5-25.5 × $5.9-6.3 \mathrm{~cm}$, ca. 4 times longer than wide, elliptic, one side narrower than the other, apex acuteacuminate, base cuneate-attenuate, primary lateral veins poorly differentiated (in dried material), arching smoothly upwards and running into leaf margins, not forming inframarginal collective vein, fine venation parallel to primary lateral veins. Inflorescence: peduncle $25 \mathrm{~cm}$ or more; spathe in flower expanded, patent to erect, ovate to elliptic, white with green midrib, the two margins shortly and unequally decurrent on peduncle, $9.5-11.5 \mathrm{~cm}$ long or more, 3.4-3.9 cm wide, 2.8 times longer than wide, larger at fruiting stage; spadix in flower $3.5-4.1 \mathrm{~cm}$ long, $0.7-0.9 \mathrm{~cm}$ diam., cylindric to subcylindric, rounded at apex, stipe $7-8 \mathrm{~mm}$ long; flowers bisexual, 2.4-3.3 mm diam, perigoniate, tepals 5-6, free at apex and fused basally, ovary $1.7-2 \mathrm{~mm}$ diam., stylar region not exserted from tepals, stigma slightly prominent, 3-lobed. Infructescence (immature) $5.6 \mathrm{~cm}$ long, $1.6 \mathrm{~cm}$ diam., berries (immature) $4.3-4.7 \mathrm{~mm}$ diam.

Selected material: Crato, XI.1838, G. Gardner 1867 (lectotype, K, chosen by Bunting 1960). Granjeiro (near Crato), IX.1933, P. Luetzelburg 25842 (M, not seen, cited by Bunting, 1960, p. 20).

The species preliminary conservation status assessment within Ceará is Data Deficient. Only known from two localities. It occurs in the following Montane forest area: Araripe. The label of the holotype specimen reads: "1867. Pothos sp. About 2 feet high, banks of the river near Crato. Spathe white with a green central rib. Nov. 1838." This species appears to be rare in Ceará, as we have seen no other collections, and may be threatened. It is almost certainly a plant of damp ground in the shade of gallery forest. Our description is based on the holotype material at $\mathrm{K}$.

\section{Spirodela Schleiden}

13.1 Spirodela intermedia W. Koch, Ber. Schweiz. Bot. Ges. 41(1): 113. 1932. Figs.: Pott \& Cervi (1999: Figs. 1-11, 77). Souza \& Lorenzi (2005: 97). Gonçalves \& Lorenzi (2007: 227), (2011: 281).

Small aquatic plant free-floating on the water surface. Roots 7-20 per frond. Plant body a single undifferentiated thallus, not differentiated into stem and leaves. Fronds in groups of up to 7, elliptic to orbicular, asymmetric, up to $8 \mathrm{~mm}$ long, underside inflated or not, veins 9-12. Flowers not observed (described by Pott \& Cervi (1999) as follows: Flower $1.5 \mathrm{~mm}$ long, surrounded by an apically 
open prophyll, with raphides; androecium of 2 stamens of unequal size, ca. $0.4 \mathrm{~mm}$ long, anther ca. $0.25 \mathrm{~mm}$ wide; ovary with $2-5$ seminal rudiments, style short, stigma circular. Fruit 1.8-2 × 1.5-1.9 $\mathrm{mm}$, slightly winged; seeds $1-3,1.5 \times 0.75 \mathrm{~mm}$, with 15-22 longitudinal costae).

Selected material: Maranguape, 5.VIII.1935, Francis Drouet F 949346 (EAC).

The species preliminary conservation status assessment within Ceará is Data Deficient. Only known from a single locality.

\section{Syngonium Schott}

14.1 Syngonium vellozianum Schott, Oesterr. Bot. Wochenbl. 4: 418. 1854. Souza \& Lorenzi (2005: 98). Gonçalves \& Lorenzi (2007: 76), (2011: 95).

Fig. 5k

Hemi-epiphytic or rupicolous root-climbing herb of medium stature. Stem exuding milky sap when cut, internodes elongated, glossy green. Petiole green, 8.5-27 cm long, lacking apical geniculum, sheath $5.0-19 \mathrm{~cm}$ long. Leaf blade: in juvenile plants $11.5-20.9 \mathrm{~cm}$ long, anterior lobe $6.7-10 \mathrm{~cm}$ wide, sagittate to hastate, in adult plants deeply 3-5-pedatipartite, three major lobes centrally and each major lateral lobe often with a smaller external lateral lobe, central lobe ca. $21 \mathrm{~cm}$ long, $9.5 \mathrm{~cm}$ wide, ovate to elliptic, apex subacute to obtuse, cuspidate, adaxially lustrous dark green, abaxially paler. Inflorescence: peduncle 1.6-4 $\mathrm{cm}$ long, green; spathe 3-6.7 cm long, yellowish green, constricted centrally, tube persistent after flowering, blade somewhat longer than tube, deciduous after flowering; spadix $3-5.6 \mathrm{~cm}$ long, white; female zone ca. $1.7 \mathrm{~cm}$ long, intermediate sterile zone $0.4 \mathrm{~cm}$ long, male zone $2.5 \mathrm{~cm}$ long; flowers unisexual, lacking perigone, male flower consisting of a cream-coloured synandrium, ca. 0.3 $\times 0.2 \mathrm{~cm}$, female flower with ovary 2 -locular, $0.2 \times$ $0.1 \mathrm{~cm}$, ovule solitary per locule, white, $0.1 \mathrm{~cm}$ long. Selected material: Guaramiranga, IX.1910, E. Ule 9000 (K). Viçosa do Ceará, 4.III.2002, I.M. Andrade et al. 629 (EAC).

The species preliminary conservation status assessment within Ceará is Data Deficient. Only known from two localities. It occurs in the following Montane forest areas: Baturité, Ibiapaba. Only juvenile plants were seen by us in the field, but E. Ule's collection from the Serra de Baturité is of an adult flowering plant. Croat (1981) treated $S$. vellozianum as a synonym of $S$. podophyllum Schott but recent authors (e.g. Coelho et al. 2012) maintain them as separate species.
15. Taccarum Brongniart ex Schott

15.1 Taccarum ulei Engler \& K. Krause, Notizbl. Bot. Gart. Berlin 6: 116. 1914. Souza \& Lorenzi (2005: 98). Gonçalves \& Lorenzi (2007: 142, 325), (2011: 178, 399, 468).

Fig. 6a,b

Geophytic herb to ca. $80 \mathrm{~cm}$ tall. Stem a depressed-globose subterranean tuber brown externally and whitish within, roots arising around the apex. Leaf solitary. Petiole up to $76 \mathrm{~cm}$ long, smooth, cylindric, rarely sulcate towards the base, olive-green, variegated with irregular obliquely transverse patches characterized by a contrast between white on the upper side and dark green or brown on the lower side, lacking apical geniculum, sheath $0.7-4 \mathrm{~cm}$ long, greenish rose. Leaf blade in juvenile plants entire to trilobate, in adult plants bipinnatifid to dracontioid (umbrella-like in overall shape, divided into three \pm equal major segments each of which is pinnatifid to bipinnatifid), up $83 \mathrm{~cm}$ in overall length, and up to $54 \mathrm{~cm}$ maximum width, adaxially dark green, abaxially pale green, ultimate lobes usually ovate, asymmetric, acuminate, venation adaxially impressed. Inflorescence solitary, much shorter than petiole; peduncle $4.7-17.9 \mathrm{~cm}$ long; spathe $8-31 \mathrm{~cm}$ long, ovate to oblong, lacking a constriction, \pm cymbiform, externally greyish-brown or purplish-brown lower margins convolute and hiding the female zone of the spadix, internally similar but rose-tinged towards the base, upper margins \pm revolute and greenish, obscurely variegated on both surfaces with small paler spots, cuspidate at apex, persistent to fruiting; spadix $12.1-18.8 \mathrm{~cm}$ long, projecting beyond spathe, erect, male zone contiguous with female zone and much longer; flowers unisexual, lacking perigone, male flowers less dense in upper part of spadix, partially revealing the purple axis between the flowers, each a synandrium of 4-5 stamens, connective-stigmatoid hemispheric, large and rounded, creamy white or rose, smooth, projecting well beyond the pale orange anthers; female flower with whorl of 4-5 \pm clavate, white, basally rose staminodes, ovary purple-rose, stigma large, shallowly \pm 6 -lobed, pale yellow, wider than style. Berry rose-green, locules (2-)6(-10). Seeds 1 per locule, 4-9 mm long, cream with scattered red spots. Selected material: Aiuaba, 4.II.1997, M.A. Figueiredo et al. 686 (EAC). Capistrano, 27.IV.1994, L.W. LimaVerde (EAC 21526). Choró, 6.V.1997 M.A. Figueiredo (EAC 25508). Crateus, 22.II.2000, L.W. Lima-Verde 1188 (EAC). Fortaleza, 11.IV.1997, A.S.F. Castro (EAC 24832). General Sampaio, 28.IV.2007, M.F. Moro et al. 44 (EAC). Massapé, 4.II.2000, J. Batista (EAC 28843). 

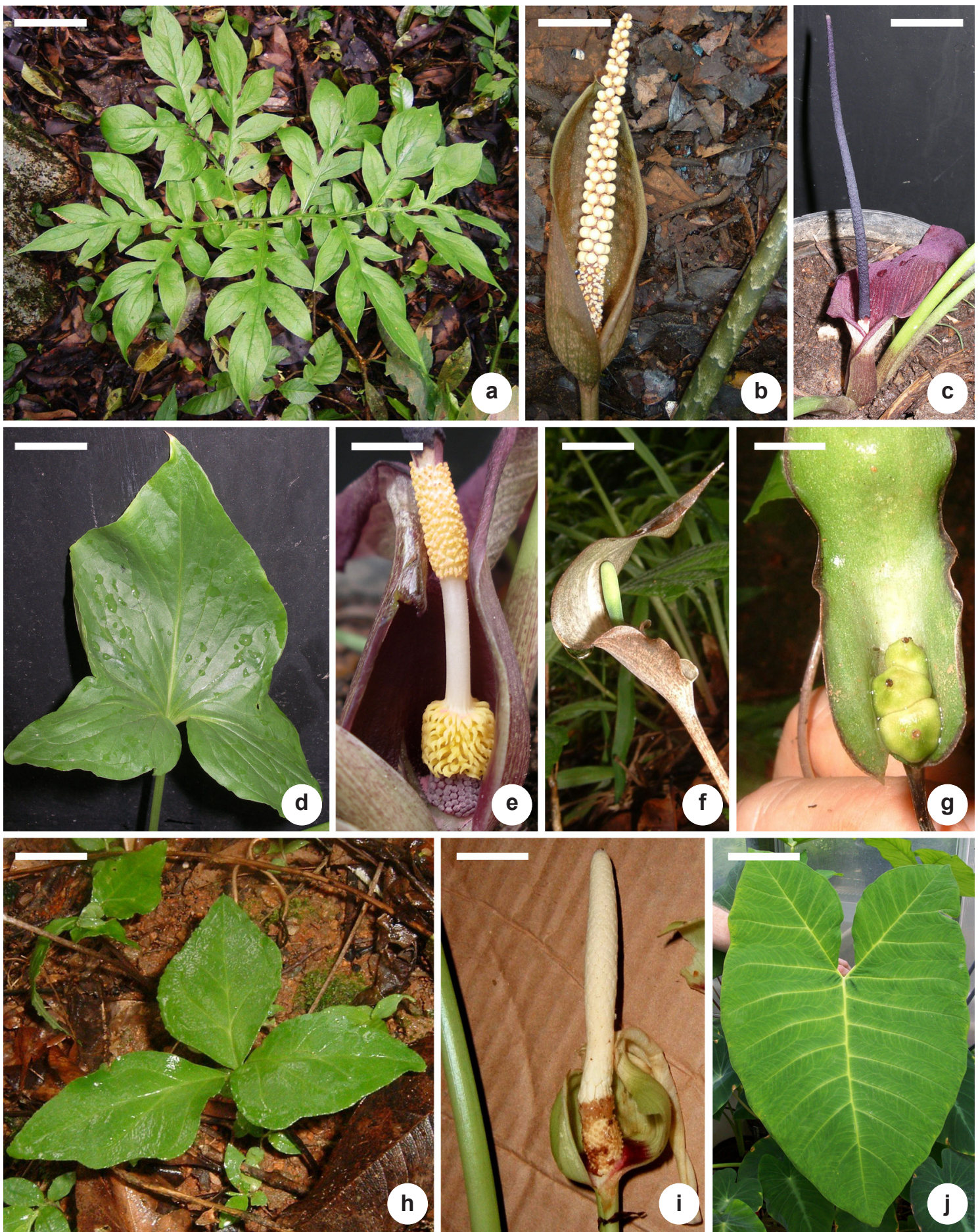

Figure 6 - a-b. Taccarum ule $-a$. leaf blade viewed from above; b. inflorescence at anthesis, showing petiole with smooth surface at right. c-e. Typhonium roxburghii (see Annex 1) - c. inflorescence, showing spadix with long blackish terminal appendix; d. leaf blade; e. spadix, showing in descending order: pale yellow male zone, white naked interstice, yellow zone of decurved staminodes and purple female zone at base. f-h. Zomicarpa pythonium $-\mathrm{f}$. inflorescence in flower; g. infructescence; h. leaf in natural habitat; i. Xanthosoma pentaphyllum - inflorescence near male anthesis, opened to show female zone; $\mathrm{j}$. Xanthosoma sagittifolium: Leaf blade, adaxial surface. Scale bars: $\mathrm{a}=7 \mathrm{~cm} ; \mathrm{b}=3$ $\mathrm{cm} ; \mathrm{c}=3 \mathrm{~cm} ; \mathrm{d}=2 \mathrm{~cm} ; \mathrm{e}=0.7 \mathrm{~cm} ; \mathrm{f}=1.2 \mathrm{~cm} ; \mathrm{g}=0.5 \mathrm{~cm} ; \mathrm{h}=2 \mathrm{~cm} ; \mathrm{i}=1.9 \mathrm{~cm} ; \mathrm{j}=10 \mathrm{~cm}$. 
Pacatuba, 17.II.2002, I.M. Andrade et al. 521 (EAC). Quixadá, 23.V.1995, L.W. Lima-Verde (EAC 22994). Santa Quitéria, 7.V.1997, M.A. Figueiredo (EAC 25555). Tianguá, 6.III.2002, I.M. Andrade et al. 634 (EAC). Ubajara, 29.I.1968, fl., D. Andrade-Lima 68-5204 (IPA). Uruburetama, 21.II.2002, I.M. Andrade et al. 550 (EAC). Viçosa do Ceará, 4.III.2002, I.M. Andrade et al. 624 (EAC).

The species preliminary conservation status assessment within Ceará is Extent of Occurrence: Least Concern (LC); Area of Occupancy: Least Concern (LC). Based on 19 specimens from 16 localities. It occurs in the following Montane forest areas: Araripe, Aratanha, Ibiapaba, Uruburetama. In Ceará this species occurs in humid, seasonal and dry forests including caatinga and carrasco. It is seasonally dormant and appears in growth during the rainy season between December and May. Gonçalves (2002) gives a full treatment of the genus. This species common names are bananade-urubu (CE), jararaca $\mathrm{CE})$, jararacataia $(\mathrm{PE})$, milho-de-cobra (CE, PE), timbó (PB).

16. Wolffia Horkel ex Schleiden

16.1 Wolffia columbiana H.Karst., Bot. Unters. 1: 103. 1865. Pott \& Cervi (1999: Figs. 67-76, 85, 88).

Fig. 3c

Very small aquatic plant-floating a few millimetres below water surface. Roots absent. Each plant an undifferentiated thallus consisting of one or two fronds, multiplying vegetatively by a daughter frond budding from a small cavity at the end of a larger frond. Fronds globose to ovoid or almost spherical, lacking air spaces, $0.8-1.3 \mathrm{~mm}$ long, pale green, translucid, unornamented, lacking veins, composed of large cells. Flowers not observed (described by Pott \& Cervi (1999) as follows:- Flower solitary, central on dorsal side of frond; stamen 0.51 mm long; ovary $0.52 \times 0.1 \mathrm{~mm}$, stigma not pigmented. Fruit $0.5 \times 0.27 \mathrm{~mm}$; seed $0.45 \times 0.23 \mathrm{~mm}$ ).

Selected material: Iguatu, 18.V.2010, L.R.O. Normando et al. 563 (EAC).

The species preliminary conservation status assessment within Ceará is Data Deficient. Only known from two localities. Wolffia columbiana occurs in association with other species of Lemnoideae (Landolt 1999) and this fact, together with its very small size, may explain why there are so few records for Ceará. The species is however distinctive (when observed under a microscope) in floating just below the water surface and in its almost spherical fronds with dilated cells (Pott \& Cervi 1999).
17. Wolffiella Hegelm.

17.1 Wolffiella welwitschii (Hegelm.) Monod, Mém. Soc. Hist. Nat. Afrique Nord., hors-ser. 2: 229. 1949. Pott \& Cervi (1999: Figs. 27-37, 81-82).

Fig. 3d,e

Very small aquatic plant free-floating a few millimetres below water surface, submersed with emersed base when in flower. Roots absent. Plant body a single undifferentiated thallus. Fronds flattened, elongated, orbicular to ovate, sometimes falcate, sometimes filiform, reflexed, 2.5-5.50 $\times$ 1.5-3.5 mm, joined with another or with others by the vegetative cavity, with or without pigmentation, aerenchyma occupying $1 / 4-1 / 2$ of the frond length, present in fertile fronds. Flower solitary in a floral cavity situated on one side of the median line, or two such floral cavities present, one on each side of median line; stamen solitary and monothecous, 0.30-0.45 mm long; gynoecium solitary, stigma discoid, ca. $0.2 \mathrm{~mm}$ diam. Fruits not observed.

Selected material: Fortaleza, 19.XI.2010, D.J.L. Sousa et al. 113 (EAC).

The species preliminary conservation status assessment within Ceará is Data Deficient. Only known from two localities. Wolffiella welwitschii occurs in association with $W$. lingulata (Hegelm.) Hegelm., Lemna aequinoctialis Welw. and Pistia stratiotes (Landolt 1999). Pott \& Cervi (1999) reported that the species is uncommon in the Brazilian Pantanal region. The species is easily recognizable when in flower because of the two laterally situated flowers giving the fronds a bilateral symmetry (Pott \& Cervi 1999). So far the species has been recorded in Ceará only in an urban locality.

\section{Xanthosoma Schott}

18.1 Xanthosoma pentaphyllum (Schott) Engl. in Martius, Fl. bras. 3(2): 197. 1878. Gonçalves \& Lorenzi (2007: 258), (2011: 316). Fig. 6i

Seasonally dormant geophytic herb of small to medium stature up to ca. $50 \mathrm{~cm}$ height. Stem hypogeal, tuber subglobose, ca. $3 \mathrm{~cm}$ diam., bearing small detachable tubercles around leaf bases, exuding milky sap when cut. Leaves usually $1-2(-3)$. Petiole pale green, glossy, lacking apical geniculum, $18.5-58 \mathrm{~cm}$ long. Leaf blade pedatisect or trisect, leaflets usually (3-)5, 11.5-24 × 1-16.0 $\mathrm{cm}$, elliptic, apex subacute, \pm cuspidate, base cuneate to shortly angustate, paler on lower surface. Inflorescence: peduncle shorter than petiole; spathe ca. $11 \mathrm{~cm}$ long, strongly constricted between 
tube and blade, tube ca. $3.5 \mathrm{~cm}$ long, ventricose, almost globose, externally pale green, internally pale green with purplish-red patch at base, blade ca. $7.5 \mathrm{~cm}$ long, white internally, greenish-white externally, reflexed with revolute margins at male anthesis, marcescent after flowering; spadix ca. $9.5 \mathrm{~cm}$ long, erect, female zone ca. $1 \mathrm{~cm}$ long, hidden within spathe tube, intermediate sterile zone ca. $3 \mathrm{~cm}$ long, thicker than female zone at base, tapering distally, sterile male flowers (synandrodes) more elongated distally, male zone ca. $5.5 \mathrm{~cm}$ long, subcylindric, apically rounded, lacking sterile terminal appendix; flowers unisexual, lacking perigone, male flowers each a synandrium of several fused stamens, white, pollen white. Seeds ca. 10 per locule, $1.5 \times 1 \mathrm{~mm}$. Selected material: Pacatuba, 17.II.2002, I.M. Andrade et al. (EAC 33684); Uruburetama, I.M. Andrade et al. 551 (EAC).

The species preliminary conservation status assessment within Ceará is Data Deficient. Only known from three localities. It occurs in the following Montane forest areas: Aratanha, Ibiapaba, Uruburetama. Seen but not collected in the Parque Nacional de Ubajara (Ibiapaba).

18.2 Xanthosoma sagittifolium (L.) Schott in H.W. Schott \& S.L.Endlicher, Melet. Bot.: 19. 1832. Gonçalves \& Lorenzi (2007: 369), (2011: 453).

Fig. $6 \mathrm{j}$

Terrestrial herb of medium to large stature, appearing acaulescent. Stem: hypogeal, corm thick, subterranean, \pm vertical, shortly cylindric to \pm globose, externally brown, exuding milky sap when cut, producing roots in lower region. Leaves several. Petiole 18.5-58 cm long, longer than blade, green with whitish striae, lacking apical geniculum, sheathed in lower part. Leaf blade ovate to sagittate, up to ca. $60 \times 45 \mathrm{~cm}$ or more, adaxially dark green, abaxially paler and usually glaucous, anterior division longer than posterior divisions, apex subacute to obtuse and cuspidate, posterior divisions subacute and angled apically; primary lateral veins of the anterior division 5-6 per side, patent, paler than blade on both surfaces, adaxially impressed, abaxially prominent, joining to form an inconspicuous infra-marginal collective vein with 1-2 exterior marginal veins very close to the margin, finer venation arising from the primaries at a wide angle then arching towards the margin and joining together to form a sinuous interprimary vein between each pair of primaries; primary lateral veins of each posterior division on acroscopic side $2-4$, on basiscopic side 5-6, more slender, joining together to forma well developed, straight basal rib denuded near the petiole junction, sinus between posterior divisions deep and spathulate or divisions partially overlapping. Inflorescence: peduncle ca. $11 \mathrm{~cm}$ long, much shorter than petiole, erect; spathe ca. 17-28 cm long or more, strongly constricted between tube and blade, tube ca. $8 \mathrm{~cm}$ long, externally green, internally paler green, subventricose, less than half as long as blade, blade ca. $20 \mathrm{~cm}$ long, cymbiform,-externally cream to white, internally white, deciduous after anthesis; spadix ca. 13-19 cm long or more, stipitate, female zone 2-3 cm long, shorter than male, tapering distally, intermediate sterile zone 3-4 cm long, thicker proximally and tapering distally, composed of sterile male flowers (synandrodes), male zone ca. 9-12 cm long, subcylindric; flowers unisexual, lacking perigone, male flower each a creamy white synandrium composed of several fused stamens, ovary trilocular, locules $2 \mathrm{~mm}$ long, stylar regions thickened and adnate to those of adjacent gynoecia, stigma 3-4 lobed, yellowish. Seeds ca. 10 per locule.

Selected material: Guaramiranga, 19.II.2002, I.M. Andrade et al. 541 (EAC). Maranguape, 16.II.2002, I.M. Andrade et al. 507 (EAC). Pacatuba, 17.II.2002, I.M. Andrade et al. 518 (EAC, HUEFS). Pacoti, 18.II.2002, I.M. Andrade et al. 531 (EAC, KEW, UVA).

The species preliminary conservation status assessment within Ceará is Not assessed, as this species is only doubtfully native. It occurs in the following Montane forest areas: Aratanha, Baturité, Maranguape. Commonly naturalized in more humid localities and almost always associated with agriculture, gardens or other areas of human impact. Widely used throughout the tropics as a source of starch and green vegetables; there are many cultivated varieties. The species common names are taioba (CE: Braga 1960:452), mangará, mangarito (CE: Braga 1960:347-348).

\section{Zomicarpa Schott}

19.1 Zomicarpa pythonium (Mart.) Schott, Syn. Aroid. 33. $1856 . \quad$ Fig. 6f-h

Geophytic herb of small stature. Stem hypogeal, tuber pale brown, subglobose, lacking milky sap. Petiole 13-23 cm long, slender, cylindric, white basally and then green to brown, variegated, lacking apical geniculum. Leaf blade 5-8 cm long, 8-15 cm wide overall, trisect to 
pedatisect, adaxially mid to dark green and sometimes with paler patches along the midrib, abaxially glossy and paler, anterior division ca. $4.5-7.2 \mathrm{~cm}$ long, ovate-rhombic, apex acute, base cuneate, primary lateral veins 3-4 per side, joining into an infra-marginal collective vein somewhat distant from margin, posterior divisions $6-8 \mathrm{~cm}$ long, $2.6-2.9 \mathrm{~cm}$, patent, \pm perpendicular to the anterior division, asymmetric, wider on the outer side. Inflorescence: peduncle 9-10 $\mathrm{cm}$ long, much longer than spathe, green to brown and variegated with paler spots; spathe in flower ca. 5-6 cm long, lower tubular portion ca. $1.7 \mathrm{~cm}$ long, with aperture at extreme base, externally pinkish-tinged brown, upper blade $3.5 \mathrm{~cm}$ long, ca. $1 \mathrm{~cm}$ wide, fornicate over spadix, longacuminate at apex, externally brown, internally paler and whitish in places, in fruit spathe persistent and herbaceous as a whole, patent above the fruits, externally brown with minute paler spots or entirely green, internally somewhat glossy green, vinaceous at margins; spadix ca. $2.8 \mathrm{~cm}$ long: female zone entirely adnate to spathe, short, consisting of 2-3 gynoecia, ovary broadly cylindric, green, stigma as wide as ovary, male zone free, densely flowered, pollen yellow, sterile terminal appendix clavate, green, apex rounded; flowers unisexual, lacking perigone. Infructescence (as seen) with 3 immature, subprismatic berries, berries green towards apex and white towards base, stigmatic scar brown, small, circular.

Selected material: Crato, XI.1976, J. Bogner 1213 (K, M). Pacatuba, 25.III.2003, I.M. Andrade et al. 687 (EAC).

The species preliminary conservation status assessment within Ceará is Data Deficient. Only known from two localities. It occurs in the following Montane forest areas: Aratanha, Araripe. The species occurring in Ceará was previously known as $Z$. riedelianum Schott, but following Gonçalves (2012) this name is now to be regarded as a synonym of $Z$. pythonium.

\section{Acknowledgements}

The authors thank the curators of the herbaria who made their collections available for this study and the owners of the private properties who kindly allowed us access to their land. The first author is grateful to the Bentham-Moxon Trust of the Royal Botanic Gardens, Kew and WWF-Brasil for financial support.

\section{References}

Andrade, I.M. 2006. Estudos morfométricos e genéticos em populações de duas espécies de Araceae em áreas florestais do Brasil, especialmente no Ceará. Tese de Doutorado. Universidade Estadual de Feira de Santana, Feira de Santana. 297p.

Andrade, I.M. \& Mayo, S.J. 2010. Molecular and morphometric patterns in Araceae from fragmented Northeast Brazilian forests. In: Seberg, O.; Petersen G.; Barfod, A.S. \& Davis, J.R. (eds.). Diversity, phylogeny and evolution in the monocotyledons. Aarhus University Press, Aarhus. Pp. 115-128.

Andrade, I.M.; Mayo, S.J. \& França, F. (2006). Araceae. In: Giulietti, A.M.; Conceição, A. \& L.P. Queiroz (eds.). Diversidade e caracterização das fanerógamas do Semi-Árido brasileiro. Vol. 1. Associação Plantas do Nordeste, Recife. Pp. 52-55.

Andrade I.M.; Mayo, S.J.; Van den Berg, C.; Fay, M.F.; Chester, M.; Lexer, C. \& Kirkup, D. 2007. A preliminary study of genetic variation in populations of Monstera adansonii var. klotzschiana (Araceae) from north-east Brazil, estimated with AFLP molecular markers. Annals of Botany 100: 1143-1154.

Andrade, I.M.; Mayo, S.J.; Kirkup, D. \& Van den Berg, C. 2008. Comparative morphology of populations of Monstera Schott (Araceae) from natural forest fragments in Northeast Brazil using elliptic Fourier Analysis of leaf outlines. Kew Bulletin 63: 193-211.

Andrade, I.M.; Mayo, S.J.; Van den Berg, C.; Fay, M.F.; Chester, M.; Lexer, C. \& Kirkup, D. 2009. Genetic variation in natural populations of Anthurium sinuatum and A. pentaphyllum var. pentaphyllum (Araceae) from north-east Brazil using AFLP molecular markers. Botanical Journal of the Linnean Society 159: 88-105.

Andrade, I.M.; Mayo, S.J.; Kirkup, D. \& Van den Berg, C. 2010. Elliptic Fourier Analysis of leaf shape in Anthurium sinuatum Benth. ex Schott and $A$. pentaphyllum (Aubl.) G.Don (Araceae) in forest fragment populations from Northeast Brazil. Kew Bulletin 65: 3-20.

APGIII. 2009. An update of the Angiosperm Phylogenetic Group classification for the orders and families of flowering plants: APG III. Botanical Journal of the Linnean Society 161: 105-121.

Armstrong, W. Lemnaceae. Available in $<$ http:// waynesword.palomar.edu/1wayindx.htm>. Access on 26 Jul 2012.

Bogner, J. 1980. The genus Scaphispatha Brongn. ex Schott. Aroideana 3: 4-12.

Bogner, J. 1987. Morphological variation in Aroids. Aroideana 10: 4-16.

Boyce, P.C. \& Croat, T.B. 2012. The Überlist of Araceae. Available in <http:/www.aroid.org/ genera/120110uberlist.pdf $>$. Access on 17 Jan 2013. 
Braga, R. 1960. Plantas do Nordeste, especialmente do Ceará. $2^{\mathrm{a}}$ ed. Imprensa Oficial, Fortaleza. 540p.

Bunting, G.S. 1960. A revision of Spathiphyllum (Araceae). Memoirs of the New York Botanical Garden 10: 1-54.

Cabrera, L.I.; Salazar, G.A.; Chase, M.W.; Mayo, S.J.; Bogner, J. \& Dávila, P. 2008. Phylogenetic relationships of aroids and duckweeds (Araceae) inferred from coding and noncoding plastid DNA. American Journal of Botany 95: 1153-1165.

Carlo, T.A. \& Aukema, J.E. 2005. Female-directed dispersal and facilitation between a tropical mistletoe and a dioecious host. Ecology 86: 3245-3251.

Coelho, M.A.N. 2011. Espécies novas de Anthurium e Philodendron (Araceae) do sudeste brasileiro. Boletim do Museu de Biologia Mello Leitão (Nova Série) 28: 21-40.

Coelho, M.A.N.; Soares, M.L.; Sakuragui, C.M.; Mayo, S.; Andrade, I.M. \& Temponi, L.G. 2010. Araceae. In: R.C. Forzza et al. (eds.). Catálogo de plantas e fungos do Brasil. Vol. 1. Andrea Jakobsson Estúdio, Instituto de Pesquisas Jardim Botânico do Rio de Janeiro, Rio de Janeiro. Pp. 646-662.

Coelho, M.A.N.; Soares, M.L.; Sakuragui, C.M.; Mayo, S.; Andrade, I.M.; Temponi, L.G.; Gonçalves, E.G. \& Calazans, L.S.B. 2012. Araceae. In: Forzza, R.C. et al. (eds.). Lista de espécies da Flora do Brasil. Jardim Botânico do Rio de Janeiro. Available in $<$ http://floradobrasil.jbrj.gov.br/2012/FB000051>. Access on 3 Jun 2012.

Cook, C.D.K. 1996. Aquatic plant book. SPB Academic Publishing, Amsterdam. 228p.

Croat. T.B. 1981. A revision of Syngonium (Araceae). Annals of the Missouri Botanical Garden 68: 565-651.

Croat, T.B. 1983. A revision of the genus Anthurium (Araceae) of Mexico and Central America. Part I: Mexico and Middle America. Annals of the Missouri Botanical Garden 70: 211-420.

Croat, T.B. 1990. Ecology and life forms of Araceae. Aroideana 11: 4-55.

Croat, T.B. 2004. Revision of Dieffenbachia (Araceae) of Mexico, Central America, and the West Indies. Annals of the Missouri Botanical Garden 91: 668-772.

Cusimano, N.; Bogner, J.; Mayo, S.J.; Boyce, P.C.; Wong, S.Y.; Hesse, M.; Hetterscheid, W.L.A.; Keating, R.C. \& French, J.C. 2011. Relationships within the Araceae: Comparison of morphological patterns with molecular phylogenies. American Journal of Botany 98: 654-668.

Engler, A. 1878. Araceae. In: Martius, C.F.P. von; Eichler, A.W. \& Urban, I. Flora brasiliensis. München, Wien, Leipzig, 3(2): 25-224. Tab. 2-52.

Figueiredo, M.A. 1997. A cobertura vegetal do Ceará (Unidades Fitoecológicas). In: IPLANCE. Atlas do Ceará. Edições Iplance, Fortaleza. Pp. 28-29.
Gonçalves, E.G. 2002. Sistemática e evolução da tribo Spathicarpeae (Araceae). Tese de Doutorado. Universidade de São Paulo, São Paulo. 148p.

Gonçalves, E.G. 2004. Araceae from central Brazil: comments on their diversity and biogeography. Annals of the Missouri Botanical Garden 91: 457-463.

Gonçalves, E.G. 2005. A revision of Scaphispatha (Araceae - Caladieae) including a new species. Rodriguésia 56: 53-60.

Gonçalves, E.G. 2012. A revision of the small genus Zomicarpa Schott. Kew Bulletin 67: 1-7.

Gonçalves, E.G. \& Coelho, M.A.N. 2009. Araceae. In: Rizzo, J.A. (ed.). Flora dos estados de Goiás e Tocantins. Coleção Rizzo. Vol. 39. Universidade Federal de Goiás, Goiânia. 109p.

Gonçalves, E.G. \& Lorenzi, H. 2007. Morfologia vegetal: Organografia e dicionário ilustrado de morfologia das plantas vasculares. Instituto Plantarum, Nova Odessa. 416p.

Gonçalves, E.G. \& Lorenzi, H. 2011. Morfologia vegetal: Organografia e dicionário ilustrado de morfologia das plantas vasculares. $2^{\text {a }}$ ed. Instituto Plantarum, Nova Odessa.

Gonçalves, E.G. \& Temponi, L.G. 2004. Anew Monstera (Araceae: Monsteroideae) from Brazil. Brittonia 56: 72-74.

Grayum, M.H. 1990. Evolution and phylogeny of Araceae. Annals of the Missouri Botanical Garden 77: 628-677.

Hammer, Ø.; Harper, D.A.T. \& Ryan, P.D. 2001. PAST: Paleontological Statistics software package for education and data analysis. Palaeontologia Electronica Vol. 4. Pp 9.

IBAMA. 1999. Revisão do plano de manejo do Parque Nacional de Ubajara: estudo sobre a flora e a vegetação do Parque Nacional de Ubajara. Relatório do Instituto Brasileiro do Meio Ambiente e dos Recursos Naturais Renováveis (IBAMA) Fortaleza. CD-ROM.

Landolt, E. 1999. Pleustonic communities with Lemnaceae in South America. Applied Vegetation Science 2: 7-16.

Lima-Verde, L.W. \& Gomes, V.S. 2007. Plantas nativas da serra de Baturité, Ceará, com potencial ornamental. In: Oliveira, T. S. \& Araújo, F. S. (eds.). Diversidade e conservação da biota da serra de Baturité, Ceará. Seri \& A Gráfica, Fortaleza. Pp. 295-315.

Lorenzi, H. \& Souza, H.M. 2001. Plantas ornamentais no Brasil: arbustivas, herbáceas e trepadeiras. $3^{\text {a }}$ ed. Instituto Plantarum, Nova Odessa. 1088p.

Madison, M.T. 1977. A revision of Monstera (Araceae). Contr. Gray Herb. 207: 1-100 (1977).

Madison, M.T. 1981. Notes on Caladium (Araceae) and its allies. Selbyana 5: 342-377.

Maia, A.C.D.; Schlindwein, C.; Navarro, D.M.A.F. \& Gibernau. M. 2010. Pollination of Philodendron acutatum (Araceae) in the Atlantic Forest of 
Northeastern Brazil: a single scarab beetle species guarantees high fruit set. International. Journal of Plant Sciences 171: 740-748.

Matias, L.Q. \& Sousa, D. J. L. 2011. Alismataceae no estado do Ceará, Brasil. Rodriguésia 62: 887-900.

Mayo, S.J. \& Sakuragui, C.M. 2011. Typification and interpretation of Philodendron imbe Schott ex Kunth (Araceae). Taxon 60: 1764-1767.

Mayo, S.J.; Bogner, J. \& Boyce, P. 1997. The genera of Araceae. Royal Botanic Gardens, Kew. 370p.

Nicolson, D.H. \& Sivadasan, M. 1981. Four frequently confused species of Typhonium Schott (Araceae). Blumea 27: 483-497.

Oliveira, T.S. \& Araújo, F.S. 2007. Diversidade e conservação da biota da serra de Baturité, Ceará. Seri \& A Gráfica, Fortaleza. 465p.

Pompêu, M.L.M.; Macedo, C.C.L.; Rodrigues, M.E.F. \& Hirata, R.T. 2008. Projeto Yporã - Proliferação de plantas aquáticas na Represa do Guarapiranga. Disponível em $<$ http://www.sosguarapiranga.org. br>. Access on 18 Jan 2010.

Pontes, T.A. \& Alves, M. 2011. Padrões de distribuição das espécies de Araceae ocorrentes em fragmentos de floresta atlântica em Pernambuco, Brasil. Revista Brasileira de Biociências 9: 444-454.

Pott, V.J. \& Cervi, A.C. 1999. A família Lemnaceae Gray no Pantanal (Mato Grosso e Mato Grosso do Sul), Brasil. Revista Brasileira de Botânica, São Paulo 22: 153-174. Available in $<$ http://www.scielo.br/scielo. php?pid $=$ S0100-84041999000200007\&script $=$ sci arttext>. Access 23 Jul 2012.

Rivers, M.C.; Taylor, L.; Brummitt, N.A.; Meagher, T.R.; Roberts, D.L. \& Lughadha, E.N. 2011. How many herbarium specimens are needed to detect threatened species? Biological Conservation 144: 2541-2547.
Sakuragui, C.M. 2012. Two new species and a revised key for Philodendron Section Schizophyllum (Araceae). Systematic Botany 37: 43-47.

Sakuragui, C.M.; Mayo, S.J. \& Zappi, D.C. 2006. Taxonomic revision of Brazilian species of Philodendron section Macrobelium. Kew Bulletin 60: 465-513.

Santamaría, L. 2002. Why are most aquatic plants widely distributed? Dispersal, clonal growth and smallscale heterogeneity in a stressful environment. Acta Oecologica 23: 137-154.

Silva, M.F.S.; Andrade, I.M. \& Mayo, S.J. 2012. Geometric morphometrics of leaf blade shape in Montrichardia linifera (Araceae) populations from the Rio Parnaíba Delta, north-east Brazil. Botanical Journal of the Linnean Society 170: 554-572.

Sneath, P.H.A. \& Sokal, R.R. 1973. Numerical Taxonomy: The principles and practice of numerical classification. W.H. Freeman, San Francisco. 573p.

Souza, V.C. \& Lorenzi, H. 2008. Botânica sistemática. Instituto Plantarum, Nova Odessa. Pp. 98-107.

Stevens, P. F. 2001 onwards. Angiosperm Phylogeny Website. Version 9, June 2008 [and more or less continuously since]. Available in $<$ http://www. mobot.org/MOBOT/research/APweb/>. Access on 17 Jan 2013.

Thiers, B. 2010 [continuously updated]. Index Herbariorum: A global directory of public herbaria and associated staff. New York Botanical Garden's Virtual Herbarium. Available in $<$ http://sweetgum. nybg.org/ih/>. Access on 10 Nov 2010.

Tropicos.org. 2012. Missouri Botanical Garden. Available in <http://www.tropicos.org. $>$. Access on 23 Jul 2012.

Zhu, G. \& Croat, T.B. 2004. Revision of Dracontium (Araceae). Annals of the Missouri Botanical Garden 91: 593-667.

\section{Annex 1 - Naturalized exotic species recorded during this study}

Alocasia macrorrhizos (L.) G. Don in R. Sweet, Hort. Brit., ed. 3: 631 (1839). Engler (1878: 202, Tab. 46-47), Lorenzi \& Souza (2001: 190), Gonçalves \& Lorenzi (2007: 273); Taioba brava (Braga 1960: 452). Occurs usually in damp ground; widely grown in Brazil. Native to southeast tropical Asia and the Malaysian Archipelago.

Colocasia esculenta (L.) Schott in H.W. Schott \& S.L. Endlicher, Melet. Bot. 18. 1832. Taioba (Braga 1960: 452), taro, inhame, inhame-preto, inhame-imperial, tinhorão-preto (Lorenzi \& Souza 2001: 199-200). Gonçalves \& Lorenzi (2007: 100, 154, 208, 384), Lorenzi \& Souza (2001: 199-200). Cultivated and naturalized in tropical and subtropical regions of the world, usually in wet ground. Its original area of occurrence is uncertain, due to its long history of cultivation, but certainly lies somewhere in tropical Asia.

Dieffenbachia seguine (Jacq.) Schott in H.W.Schott \& S.L.Endlicher, Melet. Bot.: 20 (1832). Comigo-ninguém-pode. Lorenzi \& Souza (2001: 202, as D. amoena Bull); Croat (2004: 746-751). Cultivated and naturalized throughout the neotropics, but its original distribution is uncertain. There are many cultivated varieties known under different specific names, e.g. D. picta, D. maculata, etc., which differ in the colours and patterns of variegation of their foliage. According to the most recent taxonomic revision (Croat 2004), these varieties all belong to the same species, i.e. D. seguine. 
Epipremnum aureum (Linden \& André) G.S.Bunting, Ann. Missouri Bot. Gard. 50: 28 (1964). Jibóia. Gonçalves \& Lorenzi (2007: 287), Lorenzi \& Souza (2001: 203, identified as Epipremnum pinnatum (L.) Engl.). Cultivated throughout the world as an ornamental plant, either as a robust climber and ground cover in tropical gardens, or in its juvenile form as a small house plant in temperate regions.

Typhonium roxburghii Schott, Aroideae 1: 12 (1853). Fig. 6c-e. Nicolson \& Sivadasan (1981: 492, Fig. 3). Several species of Typhonium are naturalized in the neotropics and can be distinguished by characters of leaf shape and sterile flowers in the inflorescence. Typhonium roxbughii has a hastate leaf and the sterile flowers are rather short and acicular and characteristically deflexed, forming a compact cylindrical zone immediately above the female flowers (Nicolson \& Sivadasan 1981).

Zantedeschia aethiopica (L.) Spreng., Syst. Veg. 3: 765 (1826). Copo de leite. Lorenzi \& Souza (2001: 236). Cultivated throughout the world for its pure white spathes, much used in horticulture and in floral displays.

\section{Annex 2 - Determination list for exsiccatae}

Alencar, M.R. s.n. (EAC 20899) Philodendron ornatum; Andrade, I.M. 503 Philodendron ornatum; 504 Monstera adansonii var. klotzschiana; 507 Xanthosoma sagittifolium; 509 Philodendron ornatum; 511 Anthurium scandens; 512 Philodendron ornatum; 514 Monstera adansonii var. klotzschiana; 515 Philodendron acutatum; 518 Xanthosoma pentaphyllum; 518 Xanthosoma sagittifolium; 519 Anthurium sinuatum; 520 Caladium bicolor; 521 Taccarum ulei; 521 Taccarum ulei; 522 Dieffenbachia seguine; 523 Philodendron acutatum; 523 Philodendron ornatum; 524 Philodendron pedatum; 526 Philodendron sp. aff. ruthianum; 527 Philodendron pedatum; 528 Philodendron pedatum; 529 Anthurium sinuatum; 530 Caladium bicolor; 531 Xanthosoma sagittifolium; 533 Monstera praetermissa; 534 Anthurium scandens; 535 Philodendron ornatum; 536 Philodendron ornatum; 536 Philodendron ornatum; 537 Xanthosoma sagittifolium; 539 Philodendron pedatum; 540 Caladium bicolor; 541 Xanthosoma sagittifolium; 543 Anthurium sinuatum; 544 Monstera adansonii var. klotzschiana; 546 Monstera adansonii var. klotzschiana; 547 Monstera praetermissa; 548 Anthurium sinuatum; 550 Taccarum ulei; 551 Xanthosoma pentaphyllum; 552 Philodendron acutatum; 554 Anthurium sinuatum; 556 Anthurium sinuatum; 557 Anthurium sinuatum; 559 Anthurium sinuatum; 561 Anthurium sinuatum; 573 Monstera praetermissa; 575 Philodendron ornatum; 576 Philodendron acutatum; 577 Anthurium sinuatum; 580 Anthurium sinuatum; 581 Anthurium sinuatum; 602 Monstera adansonii var. klotzschiana; 617 Monstera adansonii var. klotzschiana; 618 Philodendron acutatum; 619 Philodendron ornatum; 620 Philodendron ornatum; 622 Scaphispatha gracilis; 623 Anthurium affine; 624 Taccarum ulei; 625 Caladium bicolor; 626 Philodendron acutatum; 627 Dracontium nivosum; 628 Dracontium nivosum; 629 Syngonium vellozianum; 630 Spathicarpa gardneri; 631 Dracontium nivosum; 633 Caladium bicolor; 634 Taccarum ulei; 635 Dracontium nivosum; 637 Spathicarpa gardneri; 656 Anthurium sinuatum; 670 Anthurium sinuatum; 671 Monstera adansonii var. klotzschiana; 679 Anthurium sinuatum; 680 Monstera adansonii var. klotzschiana; 681 Monstera adansonii var. klotzschiana; 683 Philodendron ornatum; 687 Zomicarpa pythonium; 688 Xanthosoma sagittifolium; 881 Anthurium sinuatum; 888 Monstera adansonii var. klotzschiana; s.n. (EAC 28493) Caladium bicolor; Andrade-Lima, D. 68-5195 Spathicarpa gardneri; 68-5204 Taccarum ulei; 68-5237 Anthurium sinuatum; Araújo, F.S. 668 Taccarum ulei; 1080 Taccarum ulei; s.n. (EAC 21487) Philodendron acutatum; Arruda, L.V. 9 Anthurium sinuatum; Batista, J. s.n. (EAC 28843) Taccarum ulei; Bezerra, P. s.n. Caladium bicolor; s.n. (EAC 468) Caladium bicolor; Bogner, J. 1211 Scaphispatha gracilis; 1213 Zomicarpa pythonium; Castro, A.S.F. 335 Pistia stratiotes; 1675 Montrichardia linifera; 1676 Montrichardia linifera; 2347 Philodendron acutatum; s.n. (EAC 24832) Taccarum ulei; Cavalcanti, F.S. s.n. (EAC 2842) Anthurium scandens; Drouet, F.F. 949346 Spirodela intermedia; Fernandes, A. 27781 Anthurium sinuatum; s.n. (EAC 9635) Anthurium scandens; s.n. (EAC 28495) Monstera praetermissa; s.n. (EAC 27814) Monstera praetermissa; s.n. (EAC 27815) Philodendron acutatum; s.n. (EAC 28491) Philodendron ornatum; s.n. (EAC 27811) Taccarum ulei; Figueiredo, M.A. s.n. (EAC 20057) Philodendron acutatum; 19 (EAC 17165) Spathicarpa gardneri; 686 Taccarum ulei; s.n. (EAC 17932) Spathicarpa gardneri; s.n. (EAC 25492) Philodendron acutatum; s.n. (EAC 25508) Taccarum ulei; s.n. (EAC 25847) Spathicarpa gardneri; s.n. (EAC 25555) Taccarum ulei; Gardner, G. 1867 Spathiphyllum gardneri; Gomes, M.A. s.n. Spathicarpa gardneri; Gomes, V. 763 Anthurium scandens; 780 Monstera praetermissa; 1026 Anthurium sinuatum; 1205-9 Anthurium sinuatum; 2209-1 Philodendron ornatum; s.n. (EAC 49060) Philodendron pedatum; Leal, J.B. s.n. (EAC 21528) Spathicarpa gardneri; Leopoldina s.n. (EAC 30727) Philodendron acutatum; Lima-Verde, L.W. 545 Philodendron pedatum; 549 Philodendron ornatum; 1021 Anthurium sinuatum; 1068 Scaphispatha gracilis; 1076 Scaphispatha gracilis; 1091 Scaphispatha gracilis; 1188 Taccarum ulei; s.n. (EAC 21527) Spathicarpa gardneri; s.n. (EAC 22776) Spathicarpa gardneri; s.n. (EAC 21526) Taccarum ulei; s.n. (EAC 25512) Spathicarpa gardneri; s.n. (EAC 21218) Philodendron sp.aff. r; s.n. (EAC 21126) Philodendron pedatum; s.n. (EAC 20896) Anthurium sinuatum; s.n. (EAC 23896) Monstera adansonii var. klotzschiana; s.n. (EAC 23870) Philodendron acutatum; s.n. (EAC 23890) Philodendron pedatum; 
s.n. (EAC 21841) Caladium bicolor; s.n. (EAC 22068) Philodendron pedatum; s.n. (EAC 22994) Taccarum ulei; s.n. (EAC 32057) Taccarum ulei; s.n. (EAC 25538) Philodendron acutatum; s.n. (EAC 15319) Anthurium scandens; s.n. (EAC 44019) Pistia stratiotes; s.n. (EAC 37702) Pistia stratiotes; Lopes, M.S. s.n. (EAC 26950) Anthurium scandens; Luetzelburg, P. 25941 Spathicarpa gardneri; 25977 Spathicarpa gardneri; 25984 Scaphispatha gracilis; 26838 Pistia stratiotes; Matias, L.Q. 526 Montrichardia linifera; 555 Caladium bicolor; 590 Pistia stratiotes; s.n. (EAC 29046) Pistia stratiotes; Moro, M.F. 44 Taccarum ulei; 139 Philodendron acutatum; 397 Montrichardia linifera; 474 Philodendron acutatum; Normando, L.R.O. 172 Pistia stratiotes; 196 Pistia stratiotes; 493 Lemna aequinoctialis; 496 Lemna aequinoctialis; 563 Wolffia columbiana; s.n.Wolffia columbiana; Oliveira, M.R. s.n. (EAC 20898) Anthurium scandens; Paiva, J.R.A. 18 Pistia stratiotes; Ribeiro, T.A. 44 Dieffenbachia aglaonematifolia; Rocha Neto, J.L. S.n. Lemna minuta; Sousa, D.J.L. 88 Montrichardia linifera; 113 Wolffiella welwitschii; 294 Anthurium scandens; Sousa, E.B. 402 Monstera praetermissa; 427 Anthurium scandens; s.n. (EAC 26584) Philodendron acutatum; Ule, E. 9000 Syngonium vellozianum; 9001 Anthurium scandens. 